\title{
Hepatoprotective potential of Fagonia olivieri DC. against acetaminophen induced toxicity in rat
}

\author{
Umbreen Rashid ${ }^{1}$, Muhammad Rashid Khan ${ }^{2^{*}}$ and Moniba Sajid ${ }^{2}$
}

\begin{abstract}
Background: Fagonia olivieri (DC) being used for the treatment of diabetes, cancer, fever and claimed to be effective in many other stress related disorders. In this study we have evaluated the F. olivieri whole methanol extract and its derived fractions for various in vitro and in vivo antioxidant studies.

Methods: The crude methanol extract of the whole plant of F. olivieri (FOM) and its derived fractions; $n$-hexane $(F O H)$, chloroform (FOC), ethyl acetate (FOE), n-butanol (FOB) and aqueous (FOA) were evaluated for the total phenolic and flavonoid content and in vitro antioxidant abilities. The antioxidant effect of FOM was determined by acetaminophen-induced hepatotoxicity in Sprague-Dawley (Rattus novergicus) male rats. The methanol/fractions were also analysed by HPLC analysis for the presence of polyphenolics.

Results: The total phenolic content of the samples ranged from $19.3 \pm 0.529$ to $106.2 \pm 0.892 \mathrm{mg} \mathrm{GAE} / \mathrm{g}$ extract while total flavonoid content $16.2 \pm 0.881$ to $50.1 \pm 1.764 \mathrm{mg} \mathrm{RTE} / \mathrm{g}$ extract, respectively. FOA showed highest radical scavenging activity for DPPH $\left(I C_{50}=55.2 \pm 1.212 \mu \mathrm{g} / \mathrm{ml}\right)$, ABTS $\left(I C_{50}=90.2 \pm 1.232 \mu \mathrm{g} / \mathrm{ml}\right)$ superoxide $\left(I C_{50}=\right.$ $37.1 \pm 0.643 \mu \mathrm{g} / \mathrm{ml})$ and for $\mathrm{H}_{2} \mathrm{O}_{2}\left(\mathrm{IC}_{50}=64 \pm 1.463 \mu \mathrm{g} / \mathrm{ml}\right)$. FOE exhibited the highest antioxidant activities for phosphomolybdenum $\left(I C_{50}=78.2 \pm 0.883 \mu \mathrm{g} / \mathrm{ml}\right)$ and for hydroxyl radical scavenging $\left(I C_{50}=82 \pm 2.603 \mu \mathrm{g} / \mathrm{ml}\right)$. HPLC analysis of FOM and its derived fractions showed the presence of rutin, catechin and gallic acid. Elevated levels of AST, ALT, ALP, LDH and lipid profile in serum and lipid peroxidation and DNA damages in liver; while decreased activity level of CAT, SOD, GSH-Px, GR and reduced glutathione (GSH) concentration induced with acetaminophen in rat were reverted towards the control group with cO-administration of FOM.
\end{abstract}

Conclusion: Our results showed that $F$. olivieri is a potential source of natural antioxidants, which justifies its use in folklore medicine.

Keywords: Antioxidant, Fagonia olivieri, Hepatotoxicity, Total phenolic content

\section{Background}

Free radicals are produced in living systems through normal metabolic processes of the body. The reactive oxygen species (ROS) mainly include hydroxyl radical $\left({ }^{\circ} \mathrm{OH}\right)$, superoxide anion $\left(\mathrm{O}_{2}{ }^{-}\right)$and hydrogen peroxide $\left(\mathrm{H}_{2} \mathrm{O}_{2}\right)$ are produced in small amount for different physiological functions $[1,2]$. However, increased concentrations of free radicals may result into many disorders such as atherosclerosis, arthritis, Alzheimer disease,

\footnotetext{
* Correspondence: mrkhanqau@yahoo.com

2Department of Biochemistry, Faculty of Biological Sciences, Quaid-i-Azam University, Islamabad 45320, Pakistan

Full list of author information is available at the end of the article
}

cancer etc. Radiations, pollutants, toxins, deep fried and spicy foods, chemicals and physical stress are the main sources of free radical generation. Free radicals can induce abnormal proteins, depletion of antioxidants, immune system and changes in gene expression [3]. The antioxidants such as polyphenolics can protect the biological systems against the harmful effects of oxidative processes [4]. Thus, increased consumption of plant derived products which are good sources of antioxidants is a convenient way to control the diseases induced with oxidative stress [5].

Antioxidants can be of synthetic origin and can be a great number of secondary metabolites isolated from 
plants, such as various phenolic compounds [5]. Synthetic antioxidants like butylated hydroxyanisole (BHA) and butylated hydroxytoluene (BHT) were found to have genotoxic effect [6]. Therefore, it is of considerable interest to explore the plant based derivatives for their antioxidant and other biological activities. During recent decades much interest in antioxidants especially in herbal medicines emanates from their long use in folklore medicine system and their prophylactic properties. Most of the population in developing countries depends upon medicinal plants for basic pharmaceutical care. The antioxidants possess multifacetedeness in their action and provide enormous magnitude in maintaining balance. Antioxidant constituents of herbal products may contribute towards the remedy from various ailments. Use of antioxidant rich diets in daily life has shown a negative association with morbidity and mortality [7].

Liver diseases remains a worldwide health problem and are mostly associated with oxidative stress and tissue injury. The use of synthetic medicine in treating liver diseases can at times have serious side effects. Acetaminophen is a substitute of aspirin and is used worldwide for its analgesic and antipyretic properties [8]. The chronic use of acetaminophen or intake in large doses is usually related with hepato- and nephrotoxicity in animals and humans [9]. Acetaminophen is metabolized in liver via cytochrome P450 pathway into a highly toxic metabolite, N-acetyl-p-benzoquinamine (NAPQI), which is usually conjugated with glutathione and excreted in urine [9]. Acetaminophen overdose can lead to mitochondrial dysfunction by draining stores of glutathione resulting in acute hepatic necrosis development [10]. Herbal treatments for many diseases such as hepatopathy are increasing in many countries. Most of the important drugs of the modern system of medicine have been discovered because of significant contribution of folklore knowledge of medicinal plants. There are enormous resources of medicinal plants mostly in developing countries.

F. olivieri belongs to the Zygophyllaceae family, which has about 25 genera and 240 species [11]. Regarding the medicinal uses $F$. olivieri is extensively in blood vascular, alimentary canal disorders, as antioxidant, analgesic, febrifuge, astringent and prophylactic against small-pox. This plant is also used for the treatment of cancer, asthma, urinary discharges, toothache, liver and kidney diseases in the indigenous system [12, 13]. Qualitative analysis of $F$. olivieri indicated the existence of saponins, terpenoids, alkaloids, flavonoids and cardiac glycosides [14]. F. cretica is locally used for liver troubles [15]. Thrombolytic activity has been reported for $F$. arabica [16]. Antipyretic activity in rat has been reported for $F$. indica [17]. Pareek et al. [18] investigated the in vitro and in vivo antioxidant activity of $F$. schweinfurthi through DPPH, ABTS radicals and hydrogen peroxide methods and hepatoprotective potential against $\mathrm{CCl}_{4}$ induced toxicity in HepG2 cells and in rat. Hepatoprotective activity of $F$. indica has also been reported in earlier studies $[19,20]$. Antitumor potential of F. cretica has been reported in different studies [21, 22].

The aims of our study were to determine the antioxidant activity of different fractions of methanol extract of F. olivieri compared to the quantitative content of total phenols and flavonoids in the extracts. The presence of the investigated phenolic components (quercetin, myricetin, kaempferol, catechin, gallic acid, caffeic acid, rutin and apigenin) in methanol extract was done by HPLC analysis. The methanol extract was also subjected to check its potential against acetaminophen induced hepatotoxicity in (Rattus novergicus) rats.

\section{Methods \\ Chemicals}

Sodium nitrite $\left(\mathrm{NaNO}_{2}\right)$; sodium carbonate $\left(\mathrm{Na}_{2} \mathrm{CO}_{3}\right)$; sodium hydroxide $(\mathrm{NaOH})$; folin-ciocalteu reagent; 2, 2-diphenlyl-1-picrylhydrazyl (DPPH); aluminium chloride hexahydrate $\left(\mathrm{AlCl}_{3} \cdot 6 \mathrm{H}_{2} \mathrm{O}\right)$; ferric chloride $\left(\mathrm{FeCl}_{3}\right)$; phenazine methosulphate (PMS); nitro blue tetrazolium (NBT); trichloroacetic acid (TCA); thiobarbituric acid (TBA); ammoniummolybdate; hydrogen peroxide $\left(\mathrm{H}_{2} \mathrm{O}_{2}\right)$; sodium phosphate; sulphuric acid; ethylenediaminetetraacetic acid (EDTA); 2, 2 azo bis, 3-ethylbenzothiozoline-6-sulphonic acid (ABTS); 2-deoxyribose; ascorbic acid; potassium ferricyanide $\left[\mathrm{K}_{3} \mathrm{Fe}(\mathrm{CN})_{6}\right]$; reduced glutathione $(\mathrm{GSH})$; potassium persulfate $\left(\mathrm{K}_{2} \mathrm{~S}_{2} \mathrm{O}_{8}\right)$; bovine serum albumin (BSA) and 1,2-dithio-bis nitro benzoic acid (DTNB) were purchased from Sigma Co. (St. Louis, USA). All the solvents i.e. acetonitrile, methanol, acetic acid, dimethylsulfoxide (DMSO), hexane, chloroform, ethyl acetate and butanol were purchased from Sigma-Aldrich, Germany. Chemical standards for quercetin, myricetin, kaempferol, catechin, gallic acid, caffeic acid, rutin and apigenin were of analytical grade.

\section{Plant material}

Aerial parts of F. olivieri were collected from Dhamyal Rawalpindi, Pakistan. Further identified by Dr. Saleem Ahmad and voucher specimen was deposited at Pakistan Museum of Natural History (Voucher No. 058608). Whole plant was collected and dried in shade for 1 month. Resulting dried sample was powdered using a blender and kept at room temperature in polythene bags. 


\section{Extract preparation}

Dried powdered sample $(2 \mathrm{~kg})$ of $F$. olivieri was extracted twice with $4 \mathrm{l}$ of $95 \%$ methanol at $40{ }^{\circ} \mathrm{C}$ for 7 days $\mathrm{h}$ and filtered. Filtrate was evaporated on rotary evaporator to get the crude extract (FOM). A part of crude methanol extract was suspended in distilled water $(100 \mathrm{ml})$ and sequentially fractionated twice with nhexane $(\mathrm{FOH})$, chloroform (FOC) ethyl acetate (FOE), and n-butanol (FOB), however, the aqueous soluble portion was used as residual aqueous fraction (FOA), dried and was stored at $4{ }^{\circ} \mathrm{C}$.

\section{Determination of total phenolic content}

The total phenolics of the extract and various fractions of plant were determined by a reported method [23]. A volume of $200 \mu \mathrm{l}(1 \mathrm{mg} / \mathrm{ml}$ of methanol) of the test sample was mixed with $1 \mathrm{ml}$ of distilled water for dilution. Then $10 \mathrm{ml}$ of 1:10 Folin-Ciocalteau reagent was added and the reaction misture was kept at $37{ }^{\circ} \mathrm{C}$ for $5 \mathrm{~min}$. After incubation $7 \mathrm{ml}$ of $0.115 \mathrm{mg} / \mathrm{ml} \mathrm{Na}_{2} \mathrm{CO}_{3}$ was added in the mixture and kept again at $25^{\circ} \mathrm{C}$ for for $2 \mathrm{~h}$. The absorbance of the reaction mixture was recorded at $765 \mathrm{~nm}$ using a UV-visible spectrophotometer. The total phenolics are expressed as gallic acid equivalents (GAE) in miligram per gram $(\mathrm{mg} / \mathrm{g})$ of extract.

\section{Total flavonoid content estimation}

Total flavonoid content of the extract/fractions was measured following the aluminium chloride colorimetric assay described earlier [24]. An aliquot of $0.25 \mathrm{ml}$ of extract/fractions was combined with $1.25 \mathrm{ml}$ of deionized $\mathrm{H}_{2} \mathrm{O}$, then $75 \mu \mathrm{l}$ of sodium nitrite $(5 \%)$ was added in the mixture. After 6 min $150 \mu \mathrm{l}$ of $\mathrm{AlCl}_{3}(10 \%)$ was mixed and incubated for $5 \mathrm{~min}$ with addition of $0.5 \mathrm{ml}$ of $1 \mathrm{M} \mathrm{NaOH}$. Absorbance was measured at $510 \mathrm{~nm}$ against a blank. The total flavonoid content was expressed as $\mathrm{mg}$ of rutin equivalents (RTE) per $\mathrm{g}$ of sample.

\section{HPLC analysis}

Chromatographic analysis was carried out by using Agilent RP-C8 analytical column attached to HPLC-DAD. Mobile phase A was acetonitrile-methanol-water-acetic acid (5:10:85:1) and mobile phase B was acetonitrilemethanol-acetic acid (40:60:1). A gradient of time 0-20 min for 0 to $50 \% \mathrm{~B}, 20-25 \mathrm{~min}$ for 50 to $100 \%$ $\mathrm{B}$ and then $100 \% \mathrm{~B}$ until $40 \mathrm{~min}$. The flow rate was $1 \mathrm{ml} / \mathrm{min}$ and injection volume was $20 \mu \mathrm{l}$. Standards and plant extract stock solutions were prepared in methanol, at a concentration of $200 \mu \mathrm{g} / \mathrm{ml}$ and $10 \mu \mathrm{mg} / \mathrm{ml} \mathrm{respect-}$ ively. Samples were filtered through $0.45 \mu \mathrm{m}$ membrane filter. Nine reference standards i.e. catechin, rutin, kaempferol, quercetin, gallic acid, salicylic acid, apigenin, myricetin and caffeic acid (Sigma company, USA) were run at appropriate wavelengths. Rutin and gallic acid were analyzed at $257 \mathrm{~nm}$, catechin at $279 \mathrm{~nm}$, caffeic acid at $325 \mathrm{~nm}$ and quercetin, myricetin, kampferol were analyzed at $368 \mathrm{~nm}$. The column was reconditioned for 10 min before each run. All samples were assayed in triplicate. Quantification was carried out by the integration of the peak using the external standard method. All chromatographic operations were carried out at $20-25^{\circ} \mathrm{C}$ temperature.

\section{In vitro antioxidant assays}

The following antioxidant assays were performed on all the studied extract/fractions.

\section{DPPH (1, 1-diphenyl-2-picryl-hydrazyl) radical scavenging activity}

The DPPH radical scavenging activity of extract/fractions was examined by comparison with that of a known antioxidant (ascorbic acid), using a reported method [25]. Different concentrations $(250,200,150,100,50$ and $25 \mu \mathrm{g} / \mathrm{ml}$ ) of samples dissolved in methanol were taken in test tubes $(100 \mu \mathrm{l})$ in triplicates. To prepare stock solution, $2.4 \mathrm{mg}$ DPPH was dissolved in $100 \mathrm{ml}$ of methanol. To attain an absorbance less than 1.00, the stock solution was further diluted with methanol. Then $3 \mathrm{ml}$ of this solution was added to each test tube and shaken vigorously. After $30 \mathrm{~min}$ keeping at room temperature, absorbance was measured at $517 \mathrm{~nm}$. The percent of DPPH decoloration of the samples was calculated according to the Eq. 1:

$$
\begin{aligned}
& \text { DPPH scavenging activity }(\%) \\
& =\frac{\text { Absorbance of control-Absorbance of sample }}{\quad \times 100 \quad \text { Absorbance of control }}
\end{aligned}
$$

\section{Superoxide radical scavenging assay}

The scavenging activity of the extract/fractions against superoxide anion was determined according to the method of Ponti et al. [26]. The reaction mixture containing $250 \mu \mathrm{l}$ of potassium phosphate buffer (0.05 M; pH 7.6), phenazine methosulphate $(0.02 \mathrm{M}$, $126 \mu \mathrm{l})$, nitroblue tetrazolium $(0.005 \mathrm{M}, 50 \mu \mathrm{l})$ and riboflavin $(0.05 \mathrm{M}, 150 \mu \mathrm{l})$ was mixed with $150 \mu \mathrm{l}$ of test sample $(1 \mathrm{mg} / \mathrm{ml}$ methanol $)$ at different concentrations (250, 200, 150,100, 50 and $25 \mu \mathrm{g} / \mathrm{ml}$ in methanol). The mixture was placed under the fluorescent lamp for $20 \mathrm{~min}$ to initiate the reaction. Absorbance was recorded at $560 \mathrm{~nm}$ against a blank. Ascorbic acid was used as standard. The scavenging effect was determinted by using Eq. 1. 


\section{Phosphomolybdate assay (total antioxidant capacity)}

To estimate the scavenging abilities of the plant samples phosphomolybdenum assay was conducted according to Prieto et al. [27]. Serial dilutions of the plant samples were made in DMSO. The reaction mixture was prepared by mixing of $5 \mathrm{ml}$ of $28 \mathrm{mM} \mathrm{Na}_{3} \mathrm{PO}_{4}$ and $0.6 \mathrm{M}$ $\mathrm{H}_{2} \mathrm{SO}_{4}$ with that of $4 \mathrm{mM}$ ammonium molybdate. From the sample solutions $0.2 \mathrm{ml}$ was mixed with $2 \mathrm{ml}$ of the reaction mixture and incubated in a water bath at $90{ }^{\circ} \mathrm{C}$ for $80 \mathrm{~min}$. After cooling to room temperature the absorbance was recorded at $765 \mathrm{~nm}$ against blank. The antioxidant capacity was calculated by using Eq. 1 .

\section{ABTS (2,2'-azino-bis(3-ethylbenzothiazoline-6-sulphonic acid) scavenging activity}

The ABTS scavenging ability of the extracts was determined according to the method described by Miller et al. [28]. The $\mathrm{ABTS}^{*+}$ (cation) was generated freshly by mixing the ABTS solution $(7 \mathrm{mM})$ with $2.45 \mathrm{mM} \mathrm{K} \mathrm{K}_{2} \mathrm{~S}_{8}$ and kept in dark for $8 \mathrm{~h}$. The absorbance of the ABTS was adjusted to 0.7 after measuring at $745 \mathrm{~nm}$ by the addition of ethanol (70 \%). Aliquot of $100 \mu \mathrm{l}$ of various concentrations $(250,200,150,100,50$ and $25 \mu \mathrm{g} / \mathrm{ml}$ in methanol) were added in $1 \mathrm{ml}$ of ABTS solution. Alteration in absorbance was recorded for $6 \mathrm{~min}$. By the use of Eq. 1, ABTS cation scavenging potential of plant extract was determined.

\section{Hydroxyl radical scavenging activity}

The hydroxyl radical scavenging activity was determined according to the method of Halliwell et al. [29]. DMSO was used as the solvent to dissolve and for serial dilution of the plant samples. The reaction mixture was prepared by the addition of $75 \mu \mathrm{l}$ of different concentrations of the extracts with $450 \mu \mathrm{l}$ of sodium phosphate buffer $(0.2 \mathrm{M}, \mathrm{pH} 7.0), 150 \mu \mathrm{l}$ of 2 deoxyribose $(10 \mathrm{mM})$, $150 \mu \mathrm{l}$ of $\mathrm{FeSO}_{4}$-EDTA $(10 \mathrm{mM}), 150 \mu \mathrm{l}$ of $\mathrm{H}_{2} \mathrm{O}_{2}$ $(10 \mathrm{mM})$ and $525 \mu \mathrm{l}$ of $\mathrm{H}_{2} \mathrm{O}$. After incubation at $37{ }^{\circ} \mathrm{C}$ for $4 \mathrm{~h}$, the reaction was stopped by the addition of $750 \mu \mathrm{l}$ of trichloroacetic acid (2.8\%). After that $750 \mu \mathrm{l}$ of thiobarbituric acid (1\%) in $50 \mathrm{mM} \mathrm{NaOH}$ was added and the reaction mixture was heated in water bath for 10 min. Absorbance of the reaction mixture was recorded at $520 \mathrm{~nm}$ once the mixture temperature fall to room temperature. Ascorbic acid served as standard and scavenging activity was estimated by Eq. 2 .

$$
\text { Scavenging activity }(\%)=\frac{1-\text { Absorbance of sample }}{\text { Absorbance of control }}
$$

\section{Hydrogen peroxide scavenging activity}

Hydrogen peroxide scavenging activity of the plant extract/fractions was determined by the method of Ruch et al. [30]. Serial dilutions of the plant samples were prepared in concentration of 250,200,150,100, 50 and $25 \mu \mathrm{g} / \mathrm{ml}$ in methanol. Then $100 \mu \mathrm{l}$ of each concentration was added to $300 \mu \mathrm{l}$ of $50 \mathrm{mM}$ phosphate buffer ( $\mathrm{pH}$ 7.4) followed by the addition of $0.6 \mathrm{ml}$ of $2 \mathrm{mM}$ $\mathrm{H}_{2} \mathrm{O}_{2}$ solution and kept at $37^{\circ} \mathrm{C}$ for 15 min. The absorbance of the reaction mixture was recorded at $230 \mathrm{~nm}$ against blank. Hydrogen peroxide scavenging ability (in triplicate) was calculated by following Eq. 2:

\section{Reducing power}

The reducing power of the extract/fractions was determined according to Landry et al. [31]. An aliquot of $100 \mu \mathrm{l}$ of different concentrations $(250,200,150,100,50$ and $25 \mu \mathrm{g} / \mathrm{ml}$ ) were mixed with $100 \mu \mathrm{l}$ of $0.3 \mathrm{M}$ phosphate buffer-(pH 6.8) and $100 \mu$ of-potassium ferricyanide $(10 \mathrm{mg} / \mathrm{l})$ and the reaction cocktail was placed in the incubator for $20 \mathrm{~min}$ at $80{ }^{\circ} \mathrm{C}$ for $10 \mathrm{~min}$. Then $250 \mu \mathrm{l}$ of $10 \%$ trichloroacetic acid was added to the mixture, which was then centrifuged at $3000 \mathrm{rpm}$ for $10 \mathrm{~min}$. The supernatant $(0.25 \mathrm{ml})$ was mixed with $0.25 \mathrm{ml}$ of distilled water and $0.5 \mathrm{ml}$ of ferric chloride solution $(0.1 \%)$. The absorbance of the reaction mixture was recorded at $700 \mathrm{~nm}$. Increased absorbance of the reaction mixture indicated a high reducing power.

\section{In vivo acetaminophen induced hepatotoxicity in rat Animals}

Six weak old male Sprague-Dawley rats weighing 180$200 \mathrm{~g}$ were housed in conventional cages and maintained at $24 \pm 3{ }^{\circ} \mathrm{C}$ under $12 \mathrm{~h} \mathrm{light/dark} \mathrm{cycle} \mathrm{at} \mathrm{Primate} \mathrm{Facil-}$ ity of the Quaid-i-Azam University Islamabad, Pakistan. The animals were allowed free access to standard basal and water ad libitum. The basal diet was composed of $20 \%$ protein (casein), $10 \%$ sucrose, $5 \%$ corn oil, $2 \%$ choline chloride, $1 \%$ vitamin mixture, $3.5 \%$ salt mixture and $5 \%$ fibers (cellulose). The remainder was corn starch up to $100 \%$. The use of animals in experiment was approved (Bch\#245) by Ethical Committee of Quaid-i-Azam University, Islamabad and conducted in accordance with guidelines established by the National Institute of Health (NIH guidelines Islamabad, Pakistan).

\section{Acute toxicity test}

Acute toxicity of the extract was assessed by the guidelines 425 advocated by the Organization for Economic Cooperation and Development (OECD) [32]. The animals used for acute toxicity test were kept in fasting conditions for overnight with just water availability. The plant samples were prepared in DMSO and three animals were intra-gastrically administered with dose of $50 \mathrm{mg} / \mathrm{kg}$ bw and were monitored for mortality for 2 weeks. After initial screening of toxicity higher doses of the extract/fractions i.e., 100, 200, 400, 1000, 2000, 
3000 and $4000 \mathrm{mg} / \mathrm{kg}$ bw were administered to three rats for each treatment. At these administered doses mortality and abnormal behaviour was not noticed, so one tenth of the highest dose $(400 \mathrm{mg} / \mathrm{kg}$ ) and $200 \mathrm{mg} /$ $\mathrm{kg}$ were selected for the evaluation of hepato-protective propagation activities.

\section{Experimental protocol}

To assess the hepatoprotective potential of the crude methanol extract of F. olivieri the Sprague-Dawley (Rattus novergicus) male rats were randomly divided into six groups with six rats in each. Group-I: served as normal control and received $1 \mathrm{ml}$ of saline (0.9\%). Group-II: animals were administered intragastrically $750 \mathrm{ml} / \mathrm{kg}$ of acetaminophen for 7 days [33].

Group-III: animals of this group received acetaminophen as well as $50 \mathrm{mg} / \mathrm{kg}$ of the standard drug silymarin. Group-IV and V: animals of these two groups received acetaminophen along with methanol extract of $F$. olivieri at $200 \mathrm{mg} / \mathrm{kg}$ and $400 \mathrm{mg} / \mathrm{kg}$ respectively. However, animals of Group-VI received only $400 \mathrm{mg} / \mathrm{kg}$ of $F$. olivieri methanol extract. All the treatments were administered intragastrically through feeding tube in the morning. Animals were euthanized after light ether anesthesia after $24 \mathrm{~h}$ of the last treatment. The blood was collected by cardiac puncture into plain tubes and stored at $4{ }^{\circ} \mathrm{C}$.

\section{Body weight and organ weight}

Body weight of each animal in a specific group was recorded before and after the experimentation. On the basis of initial and final weight percent increase in body weight was estimated. After euthesia liver was removed, rinsed in cold saline, weighted and relative liver weight was determined for each animal of a group.

\section{Haematological studies}

Various haematological parameters such as percent of packed cell volume (PCV), haemoglobin (g/l), mean corpuscular volume $(\mathrm{MCV})$ in femtolitres $(\mathrm{fL})$, mean corpuscular haemoglobin concentration ( $\mathrm{MCHC}, \mathrm{g} / \mathrm{dl}$ ), mean corpuscular haemoglobin test $(\mathrm{MCH} ; \mathrm{pg})$ and count of whilte blood cells (WBC, $10^{3} / \mu \mathrm{l}$ ), total leukocyte count $\left(\mathrm{TLC} \times 10^{3} / \mu \mathrm{l}\right)$, platelet count (PLT $\times$ $\left.10^{3} / \mu \mathrm{l}\right)$, lymphocytes (\%), neutrophils (\%) and granulocytes (\%) were estimated through the cell dyn ruby automated 5 part hematology analyser (Abbott diagnostics, Germany).

\section{Blood serum studies}

We have estimated the level of liver markers enzymes (alanine aminotransferase (ALT), aspartate aminotransferase (AST), alkaline phosphatase (ALP), lactate dehydrogenase (LDH), total bilirubin and protein, lipid profile (total cholesterol, low-density lipoprotein (LDL), high-density lipoprotein (HDL) and triglyceride by using standard AMP diagnostic kits (Stattogger Strasse 31b 8045 Graz, Austria).

\section{Assessment of oxidative stress}

Liver tissue homogenates were prepared in 10 volume of $100 \mathrm{mM} \mathrm{KH}_{2} \mathrm{PO}_{4}$ buffer containing 1 mM EDTA (pH 7.4) and centrifuged at $12,000 \times \mathrm{g}$ for $30 \mathrm{~min}$ at $4{ }^{\circ} \mathrm{C}$. The supernatant was collected and used for the estimation of oxidative stress. The concentration of protein in the supernatant of hepatic homogenate was assessed using crystalline BSA as standard.

\section{Catalase assay (CAT)}

Catalase activities in the supernatant obtained from liver homogenates were estimated by the method of Chance and Maehly [34]. The reaction mixture for CAT activity was prepared by the addition of $2.5 \mathrm{ml}$ of $50 \mathrm{mM}$ phosphate buffer ( $\mathrm{pH} 5.0), 0.4 \mathrm{ml}$ of $5.9 \mathrm{mM} \mathrm{H}_{2} \mathrm{O}_{2}$ and $0.1 \mathrm{ml}$ of the supernatant. Changes in absorbance of the reaction solution at $240 \mathrm{~nm}$ were determined for $1 \mathrm{~min}$. One unit of CAT activity was defined as an absorbance change of $0.01 / \mathrm{min}$. The results are expressed in units/ mg protein.

\section{Superoxide dismutase assay (SOD)}

In the liver homogenates of various groups SOD activity was estimated by the method of Kakkar et al. [35]. To concentrate the superoxide dismutase enzyme in the upper layer of supernatant the liver homogenate was centrifuged at $10,000 \mathrm{~g}$ for $15 \mathrm{~min}$. A volume of $150 \mu \mathrm{l}$ of the supernatant was added to the reaction mixture containing $0.6 \mu \mathrm{l}$ of sodium pyrophosphate buffer $(0.052 \mathrm{mM}, \mathrm{pH} 7.0)$ and $50 \mu \mathrm{l}$ of phenazine methosulphate $(186 \mu \mathrm{M})$. Finally, $100 \mu \mathrm{l}$ of NADH $(780 \mu \mathrm{M})$ was added to initiate enzymatic reaction. Glacial acetic acid $(0.5 \mathrm{ml})$ after $1 \mathrm{~min}$ was added in the reaction mixture to stop the reaction. Absorbance was determined at $560 \mathrm{~nm}$ to quantify the color intensity. Results were expressed in units/mg protein.

\section{Glutathione reductase assay (GR)}

Glutathione reductase activity was determined by following the method of Carlberg and Mannervik [36]. Liver supernatant $0.1 \mathrm{ml}$ was added in the reaction mixture consisted of $1.65 \mathrm{ml}$ phosphate buffer $(0.1 \mathrm{M}$; $\mathrm{pH} 7.6), 0.1 \mathrm{ml}$ of EDTA $(0.5 \mathrm{mM}), 0.05 \mathrm{ml}$ of oxidized glutathione $(1 \mathrm{mM})$ and $0.1 \mathrm{ml}$ of NADPH (0.1 mM). Decomposition of NADPH was measured spectrophotometrically at $340 \mathrm{~nm}$ at $25{ }^{\circ} \mathrm{C}$. GR activity was determined by multiplying the absorbance value obtained with molar extinction coefficient of $6.23 \times 10^{3} / \mathrm{M} / \mathrm{cm}$ and were expressed as amount of $\mathrm{NADPH}$ oxidized $/ \mathrm{min} / \mathrm{mg}$ protein. 


\section{Glutathione peroxidase assay (GSH-Px)}

Glutathione peroxidase activity was assayed by the method of Mohandas et al. [37]. An aliquot of $0.1 \mathrm{ml}$ of the hepatic supernatant was mixed with the reaction mixture consisted of $1.49 \mathrm{ml}$ of phosphate buffer $(0.1 \mathrm{M}$; $\mathrm{pH} 7.4), 0.1 \mathrm{ml}$ of EDTA ( $1 \mathrm{mM}), 0.1 \mathrm{ml}$ of sodium azide $(1 \mathrm{mM}), 0.05 \mathrm{ml}$ of glutathione reductase $(1 \mathrm{IU} / \mathrm{ml})$, $0.05 \mathrm{ml}$ of GSH $(1 \mathrm{mM}), 0.1 \mathrm{ml}$ of NADPH $(0.2 \mathrm{mM})$ and $0.01 \mathrm{ml}$ of $\mathrm{H}_{2} \mathrm{O}_{2}(0.25 \mathrm{mM})$. Oxidation of substrate i.e. NADPH was determined at $340 \mathrm{~nm}$ spectrophotometrically. Activity GSH-Px was calculated as amount of NADPH oxidized per min per $\mathrm{mg}$ protein with the aid of molar extinction coefficient of $6.23 \times 10^{3} / \mathrm{M} / \mathrm{cm}$.

\section{Reduced glutathione assay (GSH)}

Reduced glutathione was estimated by the method of Jollow et al. [38]. To estimate the concentration of GSH in the samples $1.0 \mathrm{ml}$ of liver supernatant was precipitated with $1.0 \mathrm{ml}$ of $(4 \%)$ sulfosalicylic acid. The samples were kept at $4{ }^{\circ} \mathrm{C}$ for $1 \mathrm{~h}$ and then centrifuged at $1200 \mathrm{~g}$ for $20 \mathrm{~min}$ at $4{ }^{\circ} \mathrm{C}$. Then from the supernatant $0.1 \mathrm{ml}$ was added in the mixture consisted of $2.7 \mathrm{ml}$ of phosphate buffer $(0.1 \mathrm{M}$; pH 7.4) and $0.2 \mathrm{ml}$ of dithiobis nitro benzoic acid (DTNB, $100 \mathrm{mM}$ ). GSH reacts with DTNB and produces a yellow colored complex. Absorbance was measured at $412 \mathrm{~nm}$. It was expressed as $\mu \mathrm{M}$ GSH/g tissue.

\section{Estimation of lipid peroxidation assay (TBARS)}

The assay for lipid peroxidation was carried out following the method of Iqbal et al. [39]. In order to assess the concentration of lipid peroxides in the liver samples; $0.2 \mathrm{ml}$ of the supernatant was added in the reaction mixture having $0.58 \mathrm{ml}$ of phosphate buffer $(0.1 \mathrm{M} ; \mathrm{pH} 7.4)$, $0.2 \mathrm{ml}$ of ascorbic acid $(100 \mathrm{mM})$, and $0.02 \mathrm{ml}$ of ferric chloride $(100 \mathrm{mM})$. The reaction mixture was incubated at $37{ }^{\circ} \mathrm{C}$ in a shaking water bath for $1 \mathrm{~h}$. The reaction was stopped by addition of $1.0 \mathrm{ml}$ of $10 \%$ trichloroacetic acid. Following addition of $1.0 \mathrm{ml}$ of $0.67 \%$ thiobarbituric acid, all the tubes were placed in boiling water bath for $20 \mathrm{~min}$ and then shifted to crushed ice-bath to cool down the mixture. It was centrifuged at $2500 \mathrm{~g}$ for $10 \mathrm{~min}$ and absorbance of the supernatant was recorded at $535 \mathrm{~nm}$ against a reagent blank. The amount of thiobarbituric acid reactive substances (TBARS) formed in each of the samples was assessed by measuring optical density of the supernatant at $535 \mathrm{~nm}$ using spectrophotometer against a reagent blank. The results were expressed as nM TBARS/min/mg tissue at $37{ }^{\circ} \mathrm{C}$ using molar extinction coefficient of $1.56 \times 10^{5} \mathrm{M}^{-1} \mathrm{~cm}^{-1}$.

\section{DNA damaging studies}

DNA damaging effects of the paracetamol in liver samples were assessed following the procedure of $\mathrm{Wu}$ et al.
[40]. Hepatic tissue $(100 \mathrm{mg})$ was homogenized in 10 volume of a solution consisting of $5 \mathrm{mM}$ Tris- $\mathrm{HCl}$, 20 mM EDTA (pH 8.0) and $0.2 \%$ triton X-100. A volume of $1.0 \mathrm{ml}$ of each sample was centrifuged at 27,000 $g$ at $4{ }^{\circ} \mathrm{C}$ for $20 \mathrm{~min}$. The pellet obtained was labelled B represent the intact chromatin whereas chromatin of the supernatant represented the fragmented and labelled $\mathrm{T}$. Supernatant and the pellet were assayed for the assessment of DNA contents using a freshly prepared diphenylamine (DPA) solution reaction. Absorbance of reaction mixture was recorded at $600 \mathrm{~nm}$ with a UV/VIS spectrophotometer. The results were expressed as amount of $\%$ fragmented DNA by the following formula:

$$
\text { Fragmented DNA }(\%)=\frac{T}{T+B} \times 100
$$

\section{Histopathological studies}

For histopathological evaluation a portion of liver was fixed in a fixative (absolute alcohol $60 \%$, formaldehyde $30 \%$, acetic acid $10 \%)$. The tissues were embedded in paraffin, sectioned at $4 \mu \mathrm{m}$ and subsequently stained with hematoxylin/eosin. Sections were studied under light microscope (DIALUX $20 \mathrm{~EB}$ ) at 40 and 100 magnifications. Slides of all treated groups were studied and photographed.

\section{Statistical analysis}

The values were expressed as mean \pm standard error. For in vivo studies, the consequences of different treatments given to animals were evaluated by one way analysis of variance which was carried by means of computer software GraphPad prism 4.0. Multiple comparisons among various treatments were made by least significance difference (LSD) method at $p$-value $\leq 0.05$. Linear regression between the $\mathrm{IC}_{50}$ values of various assays and the total phenolic and total flavonoid content were computed at $p<0.05$ and $p<0.01$.

\section{Results}

\section{Extraction yield}

The extraction yields of different fractions are given in Table 1 . The yield of the methanol extract $12.56 \%$ to that of the dry powder was recorded. Among the fractions the aqueous fraction has the maximum yield of $10.59 \%$, n-butanol $9.025 \%$, ethyl acetate $8.25 \%$, n-hexane $2.21 \%$ and the chloroform fraction with $1.98 \%$ yield to that of the methanol extract.

\section{Total phenolic content}

Total phenolic content as measured by folin-Ciocalteu method, werre reported as gallic acid equivalents (GAE) are presented in Table 1. The highest amount of 
Table 1 Total phenolic and flavonoid content and extraction yield of F. olivieri fractions

\begin{tabular}{lllc}
\hline & Total phenolics (mg gallic acid equivalent/g) & Total flavonoids (mg rutin equivalent/g) & Extraction yield (\%) \\
\hline Methanol extract & $32 \pm 1.202^{\mathrm{e}}$ & $16 \pm 0.881^{\mathrm{e}}$ & 12.56 \\
n-Hexane fraction & 0.00 & 0.00 & 2.21 \\
Chloroform fraction & $44 \pm 1.263^{\mathrm{d}}$ & $26 \pm 0.666^{\mathrm{d}}$ & 1.98 \\
Ethyl acetate fraction & $106 \pm 0.892^{\mathrm{a}}$ & $40 \pm 1.155^{\mathrm{b}}$ & 8.25 \\
n-Butanol fraction & $48 \pm 2.517^{\mathrm{c}}$ & $32 \pm 0.873^{\mathrm{c}}$ & 9.025 \\
Aqueous fraction & $66 \pm 0.333^{\mathrm{b}}$ & $50 \pm 1.764^{\mathrm{a}}$ & 10.59 \\
\hline
\end{tabular}

Mean \pm SE $(n=3)$. Means not sharing the same letter ${ }^{\left({ }^{a-e}\right)}$ are significantly different (LSD) at $p<0.01$ probability level in each column. Crude methanol extract yield was based on the dry weight of powder whereas the fractions yield was based on the dry weight of crude methanol extract

phenolic content was found in the aqueous fraction (50 $\pm 1.764 \mathrm{mg} \mathrm{GAE} / \mathrm{g}$ extract), while the least amount was observed in the methanol extract $(16 \pm 0.881 \mathrm{mg} / \mathrm{g}$ GAE). Presence of phenolic contents was not indicated in the $\mathrm{n}$-hexane fraction (Table 1).

\section{Total flavonoid content}

Total flavonoid contents of different fractions are also shown in Table 1. The flavonoid contents of the extracts in terms of rutin equivalent (RTE) were between $19 \pm$ 0.529 and $106 \pm 0.892 \mathrm{mg} / \mathrm{g}$ extract with the descending order of ethyl acetate $>$ aqueous $>$ n-butanol $>$ chloroform $>$ methanol. The occurrence of flavonoid contents was not indicated in the $n$-hexane fraction.

\section{HPLC analysis of nethanol extract}

In this study, nine phenolic compounds have been investigated in F. olivieri extract and the chromatographic profiles of polyphenolics is presented in Table 2 . The HPLC fingerprinting of $F$. olivieri extract revealed the presence of gallic acid, caffeic acid, rutin, myricetin and catechin (Fig. 1). These polyphenols were identified by comparing the retention times and UV spectra to authentic standards analyzed under identical analytical conditions. Among the polyphenolics rutin was recorded in methanol extract $(2.831 \mu \mathrm{g} / \mathrm{mg}$ dry weight), ethyl acetate fraction $(2.145 \mu \mathrm{g} / \mathrm{mg}$ dry weight) and in $\mathrm{n}$ butanol fraction $(0.544 \mu \mathrm{g} / \mathrm{mg}$ dry weight). Catechin showed its presence in methanol extract $(0.101 \mu \mathrm{g} / \mathrm{mg}$ dry weight), ethyl acetate $(0.0768 \mu \mathrm{g} / \mathrm{mg}$ dry weight $)$ and in aqueous fraction $(0.824 \mu \mathrm{g} / \mathrm{mg}$ dry weight). The HPLC fingerprints revealed the existence of gallic acid in n-butanol $(0.049 \pm 0.002 \mu \mathrm{g} / \mathrm{mg}$ dry weight $)$ and aqueous fraction $(0.529 \mu \mathrm{g} / \mathrm{mg}$ dry weight).

\section{In vitro antioxidant studies \\ DPPH scavenging activity}

The $50 \%$ scavenging of $\mathrm{DPPH}$ radical $\left(\mathrm{IC}_{50}\right)$ of the methanol extract and its different fractions is presented in Table 3. A lower $\mathrm{IC}_{50}$ value would reflect greater antioxidant activity of the sample. In the present study the highest radical scavenging activity was shown by the aqueous extract $\left(\mathrm{IC}_{50}=55 \pm 1.212 \mu \mathrm{g} / \mathrm{ml}\right)$, whereas the n-hexane extract showed lowest activity $\left(\mathrm{IC}_{50}=227 \pm\right.$ $1.0 \mu \mathrm{g} / \mathrm{ml})$. The extract and fractions exhibited dose dependent scavenging of DPPH (Fig. 2).

\section{Superoxide radical scavenging activity}

The superoxide radical scavenging activity of the extract/fractions is presented in Table 2, as determined in vitro by the riboflavin-NBT-light system. The highest scavenging activity was determined in aqueous extract $\left(\mathrm{IC}_{50}=37.1 \pm 0.643 \mu \mathrm{g} / \mathrm{ml}\right)$. The methanol extract, ethyl acetate, chloroform and $n$-butanol fraction exhibited $\mathrm{IC}_{50}$ value of $137.8 \pm 2.339,53.1 \pm 1.721,85.8 \pm 1.091$ and $68.5 \pm 1.200 \mu \mathrm{g} / \mathrm{ml}$, respectively. $n$-Hexane fraction exhibited the lowest superoxide radical scavenging activity with $\mathrm{IC}_{50}$ value of $159 \pm 1.475 \mu \mathrm{g} / \mathrm{ml}$ (Table 3 ).

Table 2 Polyphenolics composition of F. olivieri fractions by HPLC

\begin{tabular}{llccc}
\hline Plant extracts & Phenolic compounds & Retention Time $(\mathrm{min})$ & Wavelength $(\mathrm{nm})$ & Concentration $(\mu \mathrm{g} / \mathrm{mg}$ dry weight) \\
\hline FOM & Catechin & 8.122 & 279 & 0.101 \\
& Rutin & 14.349 & 257 & 2.831 \\
FOE & Catechin & 8.122 & 279 & 0.076 \\
& Rutin & 14.349 & 257 & 2.145 \\
FOB & Gallic acid & 4.4 & 257 & 0.049 \\
& Rutin & 14.349 & 257 & 0.544 \\
FOA & Gallic acid & 4.4 & 257 & 0.529 \\
& Catechin & 8.122 & 279 & 0.824 \\
\hline
\end{tabular}




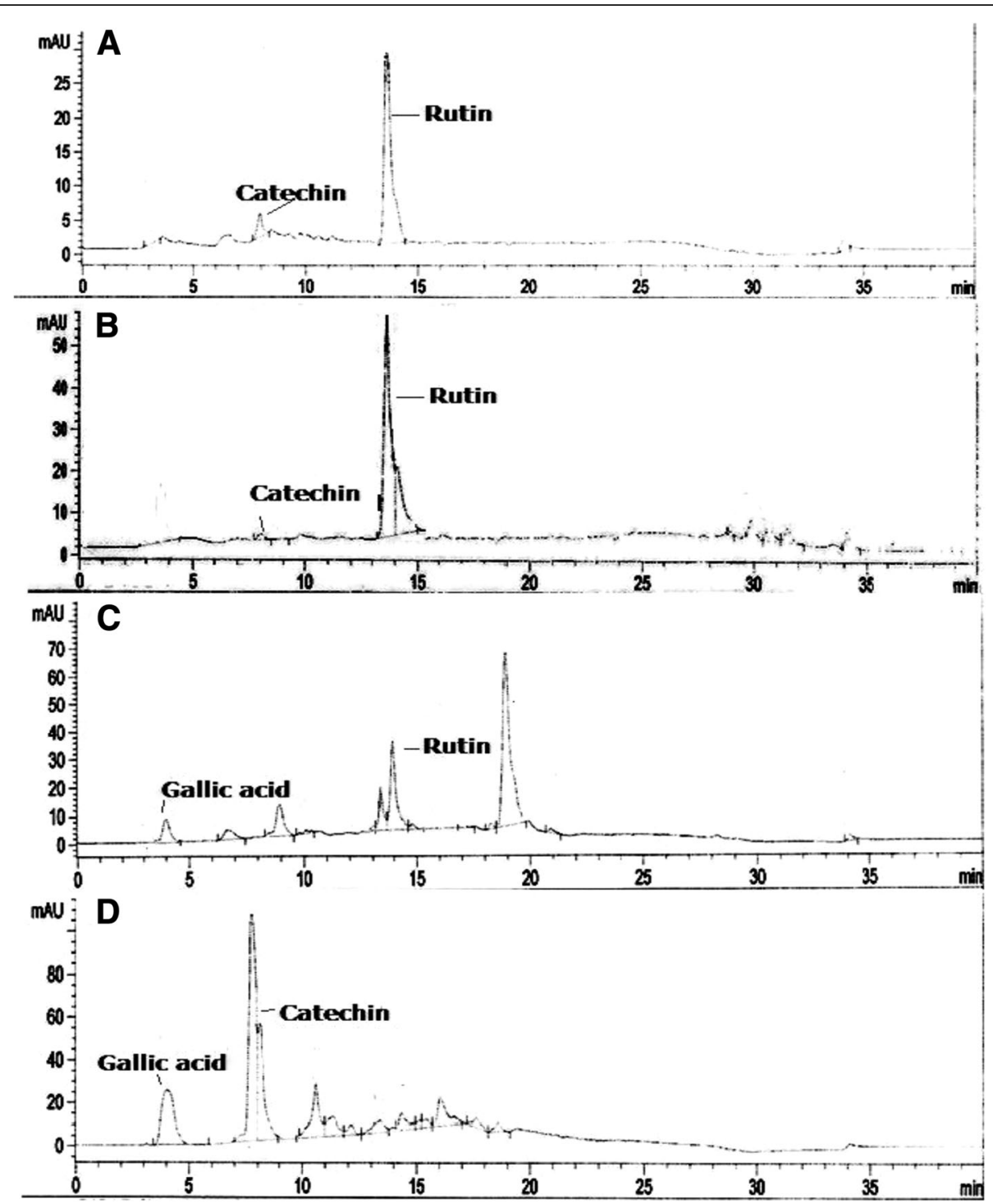

Fig. 1 HPLC fingerprint of methanol extract of F. olivieri and its derived fractions. (a) FOM, F. olivieri methanol extract; (b) FOE, F. olivieri ethyl acetate fraction of FOM; (c) FOB, F. olivieri n-butanol fraction of FOM; (d) FOA, F. olivieri soluble residual aqueous fraction of FOM

The extract/frcations exhibited dose dependent response for superoxide radical scavenging activity (Fig. 2).

\section{Phosphomolybdenum assay}

Phosphomolybdenum assay was used to determine the antioxidant capacity of the extract/fractions of F. olivieri. It relies on Mo (IV) reduction to Mo (V) by the sample analyte, leading to the formation of green phosphate/Mo (V) compounds with absorption at $695 \mathrm{~nm}$. The extract/fractions were found to have $\mathrm{IC}_{50}$ values that decreased in the order; ethyl acetate $>$ n-butanol $>$ methanol $>$ aqueous $>$ chloroform $>$ nhexane (Table 3). There was an increase in antioxidant capacity in all the extract/fractios with increase in dose (Fig. 2).

\section{Hydroxyl radical scavenging potential}

The highest hydroxyl radical scavenging potential was shown by ethyl acetate fraction $\left(\mathrm{IC}_{50}=82 \pm 2.603 \mu \mathrm{g} / \mathrm{ml}\right)$ followed by aqueous $\left(\mathrm{IC}_{50}=91 \pm 2.186 \mu \mathrm{g} / \mathrm{ml}\right)$, chloroform $\left(\mathrm{IC}_{50}=125 \pm 1.451 \mu \mathrm{g} / \mathrm{ml}\right), \quad n$-butanol $\quad\left(\mathrm{IC}_{50}=154 \pm\right.$ $0.881 \mu \mathrm{g} / \mathrm{ml})$, methanol $\left(\mathrm{IC}_{50}=162 \pm 2.404 \mu \mathrm{g} / \mathrm{ml}\right)$ and $\mathrm{n}$ hexane $\left(\mathrm{IC}_{50}=235 \pm 1.743 \mu \mathrm{g} / \mathrm{ml}\right)$. The hydroxyl radical scavenging activity of the crude methanol extract/fractions of $F$. olivieri exhibited dose response activity (Fig. 2).

\section{Hydrogen peroxide scavenging activity}

Scavenging activity of hydrogen peroxide shown by different extract/frcations of $F$. olivieri are as follows: methanol $\left(\mathrm{IC}_{50}=71 \pm 1.202 \mu \mathrm{g} / \mathrm{ml}\right)$, n-hexane $\left(\mathrm{IC}_{50}=125 \pm\right.$ $0.819 \mu \mathrm{g} / \mathrm{ml})$, chloroform $\left(\mathrm{IC}_{50}=96 \pm 0.577 \mu \mathrm{g} / \mathrm{ml}\right)$, ethyl 
Table 3 Antioxidant effect F. olivieri on various antioxidant assays

\begin{tabular}{|c|c|c|c|c|c|c|}
\hline \multirow{2}{*}{$\begin{array}{l}\text { Plant } \\
\text { extract }\end{array}$} & \multicolumn{6}{|l|}{$\mid \mathrm{C}_{50} \mathrm{\mu g} / \mathrm{ml}$} \\
\hline & $\begin{array}{l}\text { Scavenging ability on } \\
\text { DPPH radicals }\end{array}$ & $\begin{array}{l}\text { Scavenging ability on } \\
\text { superoxide radicals }\end{array}$ & $\begin{array}{l}\text { Phospho- } \\
\text { molybdate } \\
\text { assay }\end{array}$ & $\begin{array}{l}\text { Scavenging ability on } \\
\text { hydroxyl radicals }\end{array}$ & $\begin{array}{l}\text { Scavenging ability on } \\
\text { hydrogen peroxide }\end{array}$ & $\begin{array}{l}\text { Scavenging ability } \\
\text { on ABTS radicals }\end{array}$ \\
\hline$\overline{F O M}$ & $183 \pm 1.528^{d}$ & $137.8 \pm 2.33^{\mathrm{e}}$ & $99 \pm 2.028^{c}$ & $162 \pm 2.404^{e}$ & $71 \pm 1.202^{b}$ & $269 \pm 1.525^{\mathrm{e}}$ \\
\hline $\mathrm{FOH}$ & $227 \pm 1.0^{f}$ & $159 \pm 1.475^{f}$ & $167 \pm 1.732^{f}$ & $235 \pm 1.743^{f}$ & $125 \pm 0.819^{f}$ & $>300^{f}$ \\
\hline FOC & $187 \pm 1.453^{\mathrm{e}}$ & $85.8 \pm 1.091^{d}$ & $124 \pm 1.284^{\mathrm{e}}$ & $125 \pm 1.451^{c}$ & $96 \pm 0.577^{d}$ & $255 \pm 2.021^{d}$ \\
\hline FOE & $76.5 \pm 1.014^{c}$ & $53.1 \pm 1.721^{c}$ & $78 \pm 0.883^{b}$ & $82 \pm 2.603^{b}$ & $83 \pm 1.473^{c}$ & $138 \pm 1.736^{c}$ \\
\hline FOB & $132 \pm 2.082^{d}$ & $68.5 \pm 1.200^{d}$ & $83 \pm 1.856^{c}$ & $154 \pm 0.881^{d}$ & $117 \pm 1.155^{\mathrm{e}}$ & $213 \pm 1.458^{d}$ \\
\hline FOA & $55.7 \pm 1.212^{\mathrm{b}}$ & $37.1 \pm 0.643^{b}$ & $112 \pm 2.414^{d}$ & $91 \pm 2.186^{\mathrm{b}}$ & $64 \pm 1.463^{b}$ & $90 \pm 1.232^{b}$ \\
\hline ASA & $16.5 \pm 0.82^{\mathrm{a}}$ & $21.8 \pm 1.36^{a}$ & $22.5 \pm 0.41^{\mathrm{a}}$ & $29.1 \pm 0.34^{a}$ & $23.8 \pm 1.21^{\mathrm{a}}$ & $66.5 \pm 0.74^{\mathrm{a}}$ \\
\hline Rutin & $19.8 \pm 1.12^{\mathrm{a}}$ & - & $25.8 \pm 2.62^{\mathrm{a}}$ & - & $28.5 \pm 1.26^{\mathrm{a}}$ & - \\
\hline
\end{tabular}

Mean \pm SE $(n=3)$. Means not sharing the same letter $\left({ }^{\mathrm{a}-f}\right)$ are significantly different (LSD) at $p<0.05$ probability level in each column

acetate $\left(\mathrm{IC}_{50}=83 \pm 1.473 \mu \mathrm{g} / \mathrm{ml}\right)$, n-butanol $\left(\mathrm{IC}_{50}=117 \pm\right.$ $1.155 \mu \mathrm{g} / \mathrm{ml})$ and aqueous $\left(\mathrm{IC}_{50}=64 \pm 1.463 \mu \mathrm{g} / \mathrm{ml}\right)$ (Table 3). A concentration dependent increase in scavenging potential of the extract/fractions was observed (Fig. 2).

\section{ABTS radical scavenging activity}

The scavenging activity of plant extract/frcations against ABTS radical cation is presented in Table 3 . The aqueous extract exhibited the highest value $\left(\mathrm{IC}_{50}=90 \pm\right.$ $1.232 \mu \mathrm{g} / \mathrm{ml})$ followed by ethyl acetate $\left(\mathrm{IC}_{50}=138 \pm\right.$ $1.736 \mu \mathrm{g} / \mathrm{ml}), \quad n$-butanol $\left(\mathrm{IC}_{50}=213 \pm 1.458 \mu \mathrm{g} / \mathrm{ml}\right)$, chloroform $\left(\mathrm{IC}_{50}=255 \pm 2.021 \mu \mathrm{g} / \mathrm{ml}\right)$, methanol $\left(\mathrm{IC}_{50}=\right.$ $269 \pm 1.525 \mu \mathrm{g} / \mathrm{ml}$ ) and $\mathrm{n}$-hexane (>300). All the extrac/ fractions exhibited dose response scavenging potential towards the ABTS radicals (Fig. 2).

\section{Reducing power assay}

The reducing ability of the extract/fractions of $F$. olivieri exhibited a descending trend with aqueous $>$ ethyl acetate $>n$-butanol $>$ methanol $>$ chloroform $>n$ hexane (Fig. 2).

\section{Correlation studies}

The total flavonoid contents were significantly correlated; $\mathrm{R}^{2}=0.9413, \mathrm{R}^{2}=0.8551$ and $\mathrm{R}^{2}=0.8130$ with the antioxidant activities for ABTS, DPPH and the superoxide radicals respectively (Table 4). However, low level of correlation was noticed with hydroxyl radical, hydrogen peroxide and phosphomolybdenum assay. Total phenolic content exhibited moderate level of association $\mathrm{R}^{2}=0.7329 ; p<0.05, \mathrm{R}^{2}=0.7100 ; p<0.05$ for hydroxyl and DPPH radicals respectively. For the rest of antioxidant assays medium to low level of association were recorded for superoxide radical, ABTS radical, phosphomolybdate and for hydrogen peroxide scavenging respectively (Table 4).

\section{Animal studies}

Acute toxicity studies

Actute toxicity results of this study indicated that the crude methanol extract of $F$. olivieri did not cause mortality even at its highest dose of $4000 \mathrm{mg} / \mathrm{kg}$ to rats. The abnormal behaviour was not observed for 14 days after the administration of various doses of methanol extract to rats. On the basis of these results $400 \mathrm{mg} / \mathrm{kg}$ dose was used as the highest dose for animal treatment.

\section{Effects of F. olivieri on body and liver weight}

The protective effects of $F$. olivieri against acetaminophen induced variations in the body weights are presented in Table 5. There was a decline in percent increase of body weights in rats of acetaminophentreated group $(750 \mathrm{mg} / \mathrm{kg})$ as compared to the animals of the control group. Co-administration of the rats with acetaminophen and the methanol extract of $F$. olivieri considerably $(p<0.05)$ reversed the changes in body weights of rats towards the control animals. Similar effects were studied on the body weights of rats treated with silymarin and were comparable to the higher doses $(400 \mathrm{mg} / \mathrm{kg}$ ) of $F$. olivieri. Administration of $F$. olivieri alone to rats was unable $(p>0.05)$ to change the body weights as compared to the control rats.

A considerable decline was observed in the absolute and relative weights of liver of acetaminophen treated rats as compared to control group $(p<0.05)$. Crude methanol extract at $200 \mathrm{mg} / \mathrm{kg}$ and $400 \mathrm{mg} / \mathrm{kg} \mathrm{co-}$ administration maintained the organ weight towards the control group (Table 5). Similar, results were also observed with the co-administration of silymarin $(50 \mathrm{mg} / \mathrm{kg}$ ) for the absolute and the relative weights of liver. Treatment of rats with the methanol extract alone in this experiment did not decrease the liver weights as against the control group. 
A

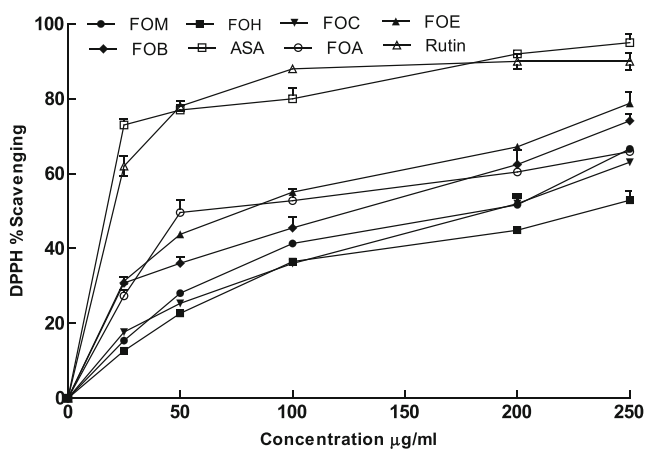

B

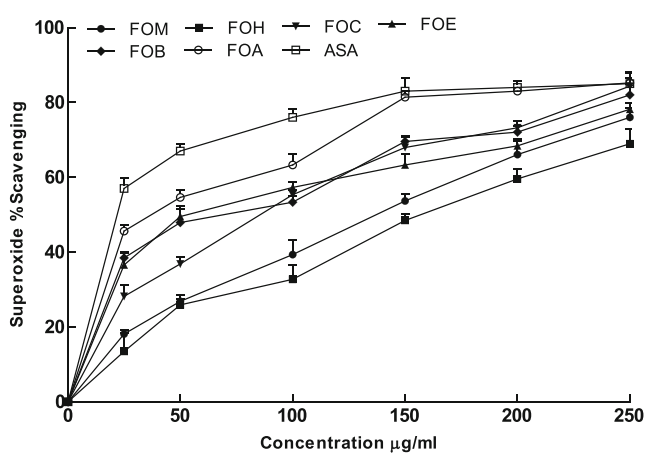

C

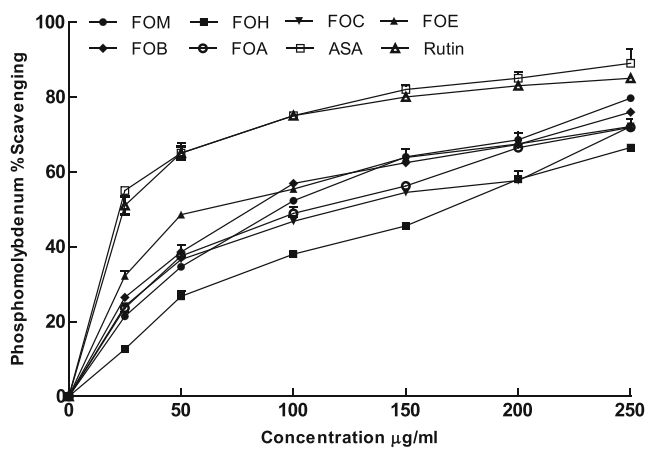

D

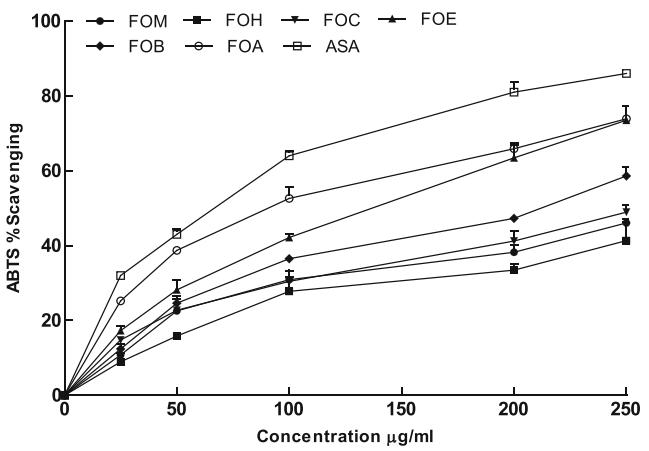

E

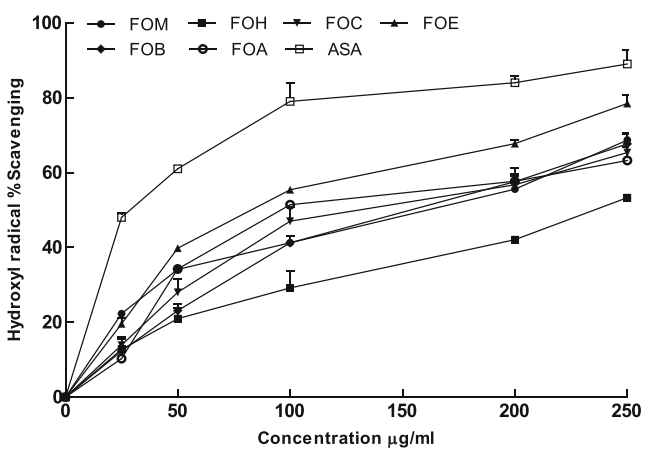

E

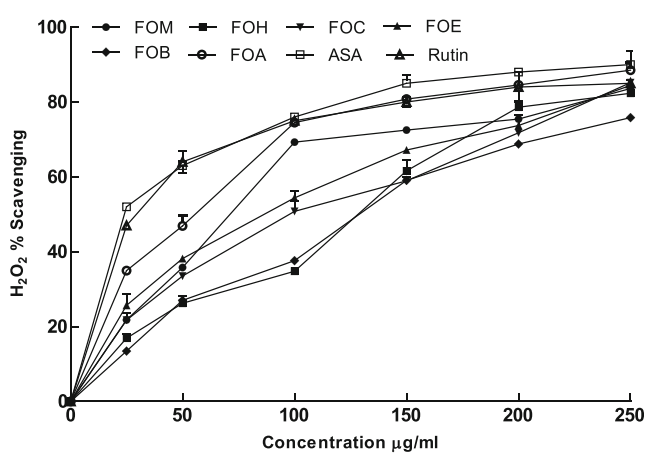

G

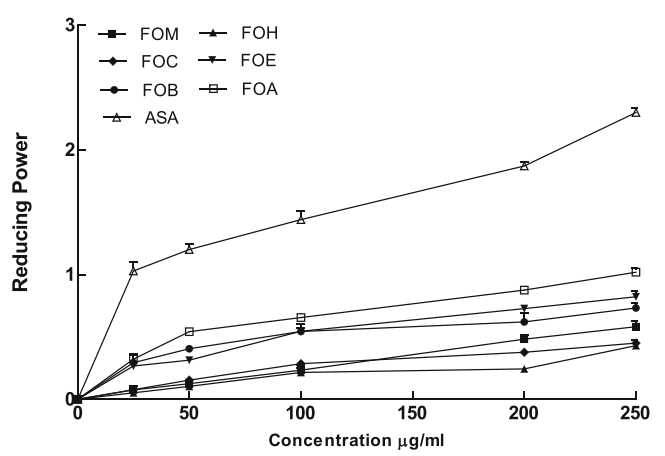

Fig. 2 (See legend on next page.) 
(See figure on previous page.)

Fig. 2 Radical scavenging activity of different fractions of F. olivieri at different concentrations. (a) DPPH; (b) superoxide; (c) phosphomolybdenum; (d) ABTS; (e) hydroxyl; (f) $\mathrm{H}_{2} \mathrm{O}_{2} ;(\mathbf{g})$ reducing power. Each value represents a mean $\pm \mathrm{SEM}(n=3)$. FOM, F. olivieri methanol extract; $F O H$, $F$. olivieri n-hexane fraction of FOM; FOC, F. olivieri chloroform fraction of FOM; FOE, F. olivieri ethyl acetate fraction of FOM; FOB, F. olivieri n-butanol fraction of FOM; FOA, F. olivieri soluble residual aqueous fraction of FOM; ASA, ascorbic acid

\section{Effects of F. olivieri on haematological parameters}

A significant decline was observed in the values of PCV, $\mathrm{Hb}, \mathrm{MCHC}$ and $\mathrm{MCH}$ while increase in $\mathrm{MCV}$ values in rats after acetaminophen administration $(p<0.05)$ as compared to the control group. Co-administration of both the doses of F. olivieri (200 and $400 \mathrm{mg} / \mathrm{kg}$ ) with acetaminophen were able to revert these values towards the control level (Table 6). Administration of F. olivieri methanol extract $(400 \mathrm{mg} / \mathrm{kg})$ alone showed non significant $(p>0.05)$ alterations as compared to the control group. However, silymarin co-administration $(50 \mathrm{mg} / \mathrm{kg})$ with acetaminophen considerably $(p<0.05)$ removed the acetaminophen toxicity and restored the values of PCV, $\mathrm{Hb}, \mathrm{MCHC}, \mathrm{MCV}$ and $\mathrm{MCH}$ towards the control rats.

After acetaminophen treatment, the values of WBC and neutrophil count were decreased significantly $(p<0.05)$ in comparison to control animals. In contrast, TLC, PLT, lymphocytes and granulocytes count elevated in acetaminophen treated animals when compared with control group. The values of WBC and neutrophils increased significantly $(p<0.05)$ in the $F$. olivieri extract co-treated groups (200 and $400 \mathrm{mg} / \mathrm{kg})$, while significant $(p<0.05)$ decrease in the count of TLC, PLT, lymphocytes and granulocytes was recorded (Table 7). Co-treatment of silymarin $(50 \mathrm{mg} / \mathrm{kg})$ with acetaminophen showed similar ameliorating effects in rats. There was not any significant change in the count of WBC, neutrophils, TLC, PLT, lymphocytes and granulocytes in the rats which were given $400 \mathrm{mg} / \mathrm{kg}$ of F. olivieri extract alone (Table 7).

\section{Effects of F. olivieri on liver marker enzymes}

The values for liver marker enzymes for acetaminophen, silymarin, F. olivieri treated rats and control group are depicted in Table 8. The values of ALT, AST, ALP and $\mathrm{LDH}$ in the serum were increased significantly $(p<0.05)$

Table 4 Correlation between antioxidant activities and total phenolic and flavonoid content

\begin{tabular}{|c|c|c|}
\hline \multirow[b]{2}{*}{$I_{50}$ values } & \multicolumn{2}{|c|}{ Correlation $\mathrm{R}^{2}$} \\
\hline & Phenolics & Flavonoids \\
\hline$I C_{50}$ of scavenging ability on DPPH radicals & $0.7100^{\mathrm{a}}$ & $0.8551^{b}$ \\
\hline $\mathrm{IC}_{50}$ of scavenging ability on superoxide radicals & 0.6253 & $0.8130^{a}$ \\
\hline $\mathrm{IC}_{50}$ of phosphomolybdate assay & 0.4562 & 0.1339 \\
\hline $\mathrm{IC}_{50}$ of scavenging ability on hydroxyl radicals & $0.7329^{a}$ & 0.5616 \\
\hline $\mathrm{IC}_{50}$ of scavenging ability on hydrogen peroxide & 0.1991 & 0.1610 \\
\hline $\mathrm{IC}_{50}$ of scavenging ability on ABTS radicals & 0.5373 & $0.9413^{b}$ \\
\hline
\end{tabular}

with acetaminophen administration indicating liver injury. The levels of total bilirubin also increased $(p<0.05)$ by acetaminophen treatment. Co-treatment of F. olivieri extract $(p<0.05)$ ameliorated the acetaminophen induced alterations in dose related pattern (200 and $400 \mathrm{mg} / \mathrm{kg}$ ). Similarly, $50 \mathrm{mg} / \mathrm{kg}$ of silymarin erased the toxicity of acetaminophen and the values of above mentioned serum parameters reversed towards the control group. Treatment of F. olivieri (400 mg/kg) alone showed non significant $(p>0.05)$ variations in the above parameters.

\section{Effects of F. olivieri on lipid profile}

The cholesterol, triglyceride, HDL and LDL levels increased significantly $(p<0.05)$ by acetaminophen administration to that of control rats. The administration of rats with the acetaminophen along with methanol extract of F. olivieri (200 and $400 \mathrm{mg} / \mathrm{kg}$ ) restored these values towards the control group (Table 9). Ameliorating effects of silymarin on the lipid profile against the acetaminophen toxicity were comparable to the higher dose of F. olivieri $(400 \mathrm{mg} / \mathrm{kg})$. Treatment of methanol extract alone displayed non significant variation in the lipid profile as compared to the control animals.

\section{Effect of F. olivieri on antioxidant enzyme armory of liver}

As shown in Table 10, the acetaminophen treatment resulted in reduced activities of hepatic antioxidant enzymes; CAT, SOD, GSH-Px and GR as compared to control animals. Co-administration of $F$. olivieri extract (200 and $400 \mathrm{mg} / \mathrm{kg}$ ) to acetaminophen treated rats significantly $(p<0.05)$ restored the level of the above mentioned antioxidant enzymes towards the control values in liver tissue. Co-treatment of silymarin $(50 \mathrm{mg} / \mathrm{kg}$ ) also restored the enzyme activities in comparison to acetaminophen treated rats. Treatment of $F$. olivieri alone did not change $(p>0.05)$ the activities of these enzymes.

\section{Effect of F. olivieri on biomolecules of liver}

The GSH and total protein content decreased whereas the TBARS and DNA damages significantly $(p>0.05)$ increased in acetaminophen treated group of rats as compared to the control rats. Co-administration of acetaminophen intoxicated rats with $F$. olivieri extract (200 and $400 \mathrm{mg} / \mathrm{kg}$ ) showed the ameliorating effects on the acetaminophen induced toxicity and the level of GSH, total protein, TBARS and DNA damages restored towards the control level. Treatment of silymarin 
Table 5 Effect of FOM body weight and liver weight in acetaminophen treated rats

\begin{tabular}{|c|c|c|c|c|c|}
\hline & Initial body weight (g) & Final body weight (g) & Percent increase in body weight & Absolute liver weight (g) & $\begin{array}{l}\text { Relative liver weight } \\
\text { (\% to body weight) }\end{array}$ \\
\hline Control (Saline) & $152.82 \pm 2.16$ & $214.83 \pm 2.21$ & $40.57 \pm 2.34^{d}$ & $7.78 \pm 1.84^{c}$ & $0.077 \pm 0.0003^{d}$ \\
\hline AMP 750 & $153.33 \pm 1.60$ & $197.62 \pm 4.85$ & $28.88 \pm 1.53^{\mathrm{a}}$ & $3.08 \pm 0.53^{\mathrm{a}}$ & $0.030 \pm 0.0001^{\mathrm{a}}$ \\
\hline AMP + Sily 50 & $156.00 \pm 3.00$ & $215.50 \pm 1.88$ & $38.14 \pm 2.26^{c}$ & $7.53 \pm 1.62^{c}$ & $0.075 \pm 0.0004^{c}$ \\
\hline AMP + FOM 200 & $154.83 \pm 1.24$ & $204.23 \pm 2.80$ & $31.90 \pm 1.75^{b}$ & $5.39 \pm 0.25^{b}$ & $0.053 \pm 0.0007^{b}$ \\
\hline $\mathrm{AMP}+\mathrm{FOM} 400$ & $153.33 \pm 1.56$ & $210.67 \pm 1.65$ & $37.39 \pm 2.92^{c}$ & $7.56 \pm 0.38^{c}$ & $0.075 \pm 0.0002^{c}$ \\
\hline FOM 400 & $158.67 \pm 1.18$ & $220.16 \pm 1.12$ & $38.75 \pm 1.64^{c}$ & $7.84 \pm 1.57^{c}$ & $0.078 \pm 0.0001^{d}$ \\
\hline
\end{tabular}

Mean \pm SEM (06). Means with different superscript letters $\left({ }^{\mathrm{a}-\mathrm{d}}\right)$ within the column indicate significant difference $(p<0.05)$. AMP, acetaminophen; FOM, F. olivieri methanol extract

$(50 \mathrm{mg} / \mathrm{kg}$ ) alleviated the toxic effects of acetaminophen and restored the above parameters towards the control group (Table 11).

\section{Histopathological analysis of liver}

Normal hepatic architecture was observed in the liver sections of control with distinct hepatocytes surrounding the central vein with clear cell membrane and nuclear structure (Fig. 3a). Liver section of acetaminophen treated animals showed hepatic degeneration, periportal inflammation, severe centrilobular necrosis with vacuolar cytoplasmic degeneration and nuclear pycnosis around the central vein (Fig. 3b). Silymarin co-treated liver samples showed improvement in the liver architecture with mild degeneration as compared to acetaminophen treated group (Fig. 3c). Administration of $F$. olivieri extracts (200 and $400 \mathrm{mg} / \mathrm{kg}$ ) results in the reduction of acetaminophen induced hepatocyte necrosis and brought the liver morphology to near normal (Fig. 3d \& e). The animals treated with $400 \mathrm{mg} / \mathrm{kg}$ of the extract alone presented the normal histoarchitecture of liver (Fig. 3f).

\section{Discussion}

The imbalance between pro-oxidants and antioxidants results into oxidative stress in the body which is promptly gaining a reputation as an important phenomenon in chronic diseases [40]. Cellular damage is the common pathway for cancer, aging and a range of diseases and antioxidants are thoroughly involved in its prevention. One of the mechanism for antioxidation is free radical scavenging action [41]. It helps the living systems to get rid of free radicals which are continuously generated and can bring about widespread damage to tissues and biomolecules [42].

In the present investigation maximum amount of total phenolic and total flavonoid contents have been recorded in the aqueous fraction of the methanol extract of F. olivieri. The antioxidant ability of the extract/fractions recorded in this study might be attributed by the polyphenols especially the rutin, gallic acid and catechin. Polyphenols present in plants are a group of highly hydroxylated phenolic compounds and includes hydroxycinnamate derivatives, hydroxycoumarins, flavanols, flavanones, flavonols, flavones, proanthocyanidins (tannins), anthocyanins, aurones, hydroxystilbenes, etc. The antioxidant activity of plant-derived phenolic compounds is exhibited through various mechanisms, including free radicals scavenging, metal ions chelation and anti-lipid peroxidation [43, 44].

This study has established the HPLC fingerprinting which is the best means of chemical characterization for the active phenolic acids. The polyphenol rutin, catechin and gallic acid found in the extract have been attributed with diverse pharmacological activities for instance, catechin with radical scavenging, iron chelation, cell signaling pathways and survival genes activation, regulation of ubiquitin-proteasome system

Table 6 Effect of FOM blood parameters in acetaminophen induced toxicity in rat

\begin{tabular}{llllll}
\hline Treatment (mg/kg bw) & PCV (\%) & Hb (g/l) & MCV (fL) & MCHC (g/dl) & MCH (pg) \\
\hline Control (Saline) & $37.23 \pm 2.13^{\mathrm{d}}$ & $13.35 \pm 0.32^{\mathrm{e}}$ & $60.23 \pm 1.50^{\mathrm{d}}$ & $33.73 \pm 1.25^{\mathrm{d}}$ & $18.62 \pm 1.28^{\mathrm{c}}$ \\
AMP 750 & $32.15 \pm 2.01^{\mathrm{a}}$ & $8.19 \pm 0.63^{\mathrm{a}}$ & $64.47 \pm 2.55^{\mathrm{a}}$ & $28.38 \pm 0.52^{\mathrm{a}}$ & $15.22 \pm 1.67^{\mathrm{a}}$ \\
AMP + Sily 50 & $37.11 \pm 1.15^{\mathrm{d}}$ & $12.93 \pm 0.31^{\mathrm{d}}$ & $61.13 \pm 1.42^{\mathrm{c}}$ & $33.19 \pm 1.51^{\mathrm{d}}$ & $18.14 \pm 1.11^{\mathrm{c}}$ \\
AMP + FOM 200 & $34.44 \pm 1.27^{\mathrm{b}}$ & $9.74 \pm 0.16^{\mathrm{b}}$ & $63.80 \pm 2.13^{\mathrm{b}}$ & $31.19 \pm 1.52^{\mathrm{b}}$ & $16.15 \pm 0.90^{\mathrm{b}}$ \\
AMP + FOM 400 & $36.32 \pm 2.05^{\mathrm{c}}$ & $10.32 \pm 0.42^{\mathrm{c}}$ & $61.69 \pm 3.82^{\mathrm{c}}$ & $32.62 \pm 1.59^{\mathrm{c}}$ & $18.19 \pm 2.50^{\mathrm{c}}$ \\
FOM 400 & $38.01 \pm 2.63^{\mathrm{e}}$ & $12.17 \pm 0.15^{\mathrm{d}}$ & $59.22 \pm 2.41^{\mathrm{e}}$ & $34.85 \pm 0.84^{\mathrm{e}}$ & $19.25 \pm 2.16^{\mathrm{d}}$ \\
\hline
\end{tabular}

Mean \pm SEM (06). Different superscript letters $\left({ }^{\text {a-e }}\right)$ within the column indicate significant difference $(p<0.05)$. AMP, acetaminophen; FOM, F. olivieri methanol extract 
Table 7 Effect of FOM on blood parameters in acetaminophen induced toxicity in rat

\begin{tabular}{|c|c|c|c|c|c|c|}
\hline Treatment (mg/kg bw) & WBC $\left(10^{3} / \mu \mathrm{l}\right)$ & $\operatorname{TLC}\left(\times 10^{3} / \mu \mathrm{l}\right)$ & $\operatorname{PLT}\left(\times 10^{3} / \mu \mathrm{l}\right)$ & Lymphocytes (\%) & Neutrophils (\%) & Granulocytes (\%) \\
\hline Control (Saline) & $7.16 \pm 0.20^{b}$ & $5.31 \pm 0.47^{c}$ & $710.16 \pm 10.64^{c}$ & $37.15 \pm 3.45^{c}$ & $60.15 \pm 3.20^{c}$ & $9.57 \pm 0.52^{e}$ \\
\hline AMP 750 & $5.62 \pm 0.22^{\mathrm{a}}$ & $7.62 \pm 0.25^{a}$ & $865.21 \pm 118.32^{\mathrm{a}}$ & $59.43 \pm 1.53^{\mathrm{a}}$ & $35.52 \pm 1.21^{\mathrm{a}}$ & $15.12 \pm 2.01^{\mathrm{a}}$ \\
\hline AMP + Sily 50 & $7.64 \pm 0.14^{d}$ & $5.11 \pm 0.43^{c}$ & $702.19 \pm 4.01^{c}$ & $40.75 \pm 2.15^{c}$ & $62.83 \pm 0.52^{c}$ & $11.77 \pm 0.84^{d}$ \\
\hline AMP + FOM 200 & $7.44 \pm 0.45^{c}$ & $6.51 \pm 0.75^{b}$ & $706.51 \pm 56.36^{c}$ & $47.18 \pm 2.11^{\mathrm{b}}$ & $41.38 \pm 1.90^{b}$ & $11.29 \pm 2.18^{d}$ \\
\hline AMP + FOM 400 & $7.82 \pm 0.54^{d}$ & $5.63 \pm 0.12^{c}$ & $843.15 \pm 23.17^{b}$ & $39.26 \pm 1.22^{c}$ & $58.71 \pm 0.95^{c}$ & $14.53 \pm 0.33^{b}$ \\
\hline FOM 400 & $7.58 \pm 0.29^{c}$ & $5.10 \pm 0.19^{c}$ & $708.16 \pm 7.89^{c}$ & $34.11 \pm 1.28^{c}$ & $63.43 \pm 1.18^{c}$ & $12.93 \pm 0.31^{c}$ \\
\hline
\end{tabular}

Mean \pm SEM (06). Means with different superscript letters $\left({ }^{a-e}\right)$ within the column indicate significant difference $(p<0.05)$. AMP, acetaminophen; FOM, F. olivieri methanol extract

and mitochondrial function [45]. Rutin exerts antioxidant, anti-inflammatory, protection against hepatotoxicity, myocardial infarction, diabetes complications, UV irradiation, and ethanol-induced gastric lesions $[46,47]$. Gallic acid endorses the antioxidant and anticancer activities [48].

In this experiment the aqueous fraction exhibited strong DPPH radical scavenging ability. DPPH stable free radical method is a rapid, sensitive and easy approach to investigate the antioxidant potential of plant extracts. Hydrogen atoms exchange between the DPPH free radical and antioxidant is the basis of this assay. In this study, the highest percentage inhibition was shown by aqueous fraction as compared to others. The results indicates that the extracts may contain compounds having the ablility of donating hydrogen to a free radical for the removal of odd electron that is in charge of radical's reactivity. Maximum scavenging potential for the DPPH radicals recorded in this investigation for the aqueous fraction might be attributed by the presence of catechin, gallic acid and other hydrogen donating antioxidants. Further, $\mathrm{IC}_{50}$ values obtained for DPPH scavenging assay also produced significant association $\left(\mathrm{R}^{2}=0.8551 ; p<0.05, \quad \mathrm{R}^{2}=\right.$ $0.7100 ; p<0.05)$ with the total flavonoid and total phenolic constituents. Our results are endorsed by a previous study where the aqueous fraction having gallic acid exhibited the strong antioxidant activity $[3,18,49]$.

Superoxide anions can harm biomolecules directly or indirectly through the formation of $\mathrm{H}_{2} \mathrm{O}_{2}, \mathrm{OH}$, singlet oxygen or peroxynitrite during the process of aging and pathological events like ischemic reperfusion injury; hence they are one of the most problematic of free radicals [48]. The potential of the extracts to destroy the superoxide radical produced from the PMS/NADH reaction is used to estimate the superoxide radical scavenging activity [50]. Our results revealed that all the extracts especially the aqueous fraction have shown the activity against this radical compared favourably with the standard reagent i.e. ascorbic acid indicating that the plant is an effective superoxide radical scavenger. The aqueous fraction of this plant also exhibited strong association $\left(R^{2}=0.8130, p<0.05\right)$ with the total flavonoid constituents that could be a therapeutic force of this plant against stress induced ailments. This electron scavenging potential of the aqueous and other fractions of this plant might be due its bioactive constituents and are responsible for the protection of macromolecules. Potent superoxide scavenging ability of the extract/fractions has been reported in earlier studies [3].

Total antioxidant capacity of the extracts can be assessed quantitatively by phosphomolybdenum assay. It has been established in this study that the highest antioxidant capacity for phosphomolybdate reduction is displayed by ethyl acetate fraction $\left(\mathrm{IC}_{50}=78 \pm\right.$ $0.883 \mu \mathrm{g} / \mathrm{ml}$ ). The results of this assay have shown the ability of the extracts to transform relative free radical species into more stable non-reactive products and to act as chain terminators [51, 52]. Phytochemical analysis of ethyl acetate fraction indicated the existence of rutin and

Table 8 Effect of F. olivieri on liver marker enzymes in acetaminophen induced toxicity in rats

\begin{tabular}{lllllc}
\hline Treatment mg/kg bw & AST (U/l) & ALT (U/l) & ALP (U/l) & LDH (U/l) & Total bilirubin (mg/dl) \\
\hline Control (Saline) & $31.90 \pm 2.31^{\mathrm{d}}$ & $25.93 \pm 5.11^{\mathrm{d}}$ & $158.65 \pm 3.00^{\mathrm{d}}$ & $53.21 \pm 1.46^{\mathrm{d}}$ & $1.18 \pm 0.17^{\mathrm{c}}$ \\
AMP 750 & $71.49 \pm 2.98^{\mathrm{a}}$ & $67.99 \pm 3.01^{\mathrm{a}}$ & $325.11 \pm 2.80^{\mathrm{a}}$ & $86.52 \pm 1.58^{\mathrm{a}}$ & $2.16 \pm 0.64^{\mathrm{a}}$ \\
AMP + Sily 50 & $63.24 \pm 1.23^{\mathrm{b}}$ & $54.87 \pm 2.67^{\mathrm{a}}$ & $231.42 \pm 2.12^{\mathrm{b}}$ & $59.38 \pm 1.34^{\mathrm{c}}$ & $2.08 \pm 0.12^{\mathrm{a}}$ \\
AMP + FOM 200 & $53.71 \pm 2.09^{\mathrm{b}}$ & $46.78 \pm 1.76^{\mathrm{b}}$ & $187.64 \pm 2.45^{\mathrm{c}}$ & $71.69 \pm 2.03^{\mathrm{b}}$ & $1.82 \pm 0.45^{\mathrm{b}}$ \\
AMP + FOM 400 & $44.39 \pm 2.31^{\mathrm{c}}$ & $38.75 \pm 2.45^{\mathrm{c}}$ & $146.73 \pm 1.91^{\mathrm{d}}$ & $56.03 \pm 1.32^{\mathrm{c}}$ & $1.29 \pm 0.58^{\mathrm{c}}$ \\
FOM 400 & $35.30 \pm 1.22^{\mathrm{d}}$ & $27.33 \pm 0.91^{\mathrm{d}}$ & $142.19 \pm 2.28^{\mathrm{d}}$ & $51.84 \pm 1.11^{\mathrm{d}}$ & $1.25 \pm 0.13^{\mathrm{c}}$ \\
\hline
\end{tabular}

Mean \pm SEM (06). Means with different superscript letters $\left({ }^{\mathrm{a}-\mathrm{d}}\right)$ within the column indicate significant difference $(p<0.05)$. AMP, acetaminophen; FOM, F. olivieri methanol extract 
Table 9 Effect of FOM on lipid profile in acetaminophen induced toxicity in rats

\begin{tabular}{|c|c|c|c|c|}
\hline Treatment (mg/kg bw) & Cholesterol (mg/dl) & Triglycerides (mg/dl) & $\mathrm{HDL}(\mathrm{mg} / \mathrm{dl})$ & $\mathrm{LDL}(\mathrm{mg} / \mathrm{dl})$ \\
\hline Control (Saline) & $96.60 \pm 3.12^{b}$ & $136.40 \pm 2.54^{c}$ & $66.42 \pm 2.54^{c}$ & $28.33 \pm 1.41^{d}$ \\
\hline AMP 750 & $126.67 \pm 3.01^{a}$ & $232.00 \pm 3.02^{a}$ & $128.65 \pm 1.32^{\mathrm{a}}$ & $67.60 \pm 2.68^{\mathrm{a}}$ \\
\hline AMP + Sily 50 & $61.12 \pm 1.31^{d}$ & $144.36 \pm 1.19^{c}$ & $69.30 \pm 2.07^{c}$ & $30.28 \pm 0.12^{c}$ \\
\hline AMP + FOM 200 & $98.00 \pm 3.07^{b}$ & $183.40 \pm 2.27^{b}$ & $108.23 \pm 1.17^{b}$ & $44.00 \pm 1.15^{b}$ \\
\hline $\mathrm{AMP}+\mathrm{FOM} 400$ & $64.00 \pm 2.12^{d}$ & $141.40 \pm 2.38^{c}$ & $72.21 \pm 1.56^{c}$ & $31.60 \pm 1.56^{c}$ \\
\hline FOM 400 & $74.26 \pm 1.52^{c}$ & $128.93 \pm 1.15^{d}$ & $63.29 \pm 1.68^{d}$ & $25.49 \pm 1.85^{\mathrm{d}}$ \\
\hline
\end{tabular}

Mean \pm SEM (06). Means with different superscript letters $\left.{ }^{\left({ }^{-d}-d\right.}\right)$ within the column indicate significant difference $(p<0.05)$. AMP, acetaminophen; FOM, F. olivieri methanol extract

catechin that might attribute the scavenging ability towards the antioxidant activity of $F$. olivieri.

A variety of molecules in living cells, for instance amino acids, nucleotides, lipids and sugars can react with hydroxyl radical because of its high reactivity. Thus hydroxyl radical scavenging is an essential antioxidant activity. In this study, the potential of the extracts to remove $\mathrm{OH}$ radicals has been linked directly with the scavenging of active species of oxygen, which reduces speed of the chain reaction. In this investigation ethyl acetate and the aqueous fraction exhibited the moderate scavenging potential for hydroxyl radicals indicating the presence of potential antioxidant phytoconstituents in F. olivieri [3, 18, 49].

The importance of hydrogen peroxide lies in its ability to penetrate biological membranes. Inside the cell, $\mathrm{H}_{2} \mathrm{O}_{2}$ can possibly react with $\mathrm{Cu}^{2+}$ and $\mathrm{Fe}^{2+}$ ions to form $\mathrm{OH}$ radical thus leading to several toxic effects. Some enzymes may directly inactivated by $\mathrm{H}_{2} \mathrm{O}_{2}$, generally by essential thiol (-SH) groups oxidation [53]. Therefore the control of $\mathrm{H}_{2} \mathrm{O}_{2}$ quantity that can build up is biologically beneficial for cells. In this study, methanol extract showed efficient scavenging of $\mathrm{H}_{2} \mathrm{O}_{2}$ that can be attributed to the presence of phenolics, which by donating electrons reduces $\mathrm{H}_{2} \mathrm{O}_{2}$ to $\mathrm{H}_{2} \mathrm{O}$. Methanol extract and its derived fractions showed admirable antioxidant activity to eliminate the hydrogen peroxide from the system. These findings are in line with the previous studies $[3,18]$.

ABTS free radical-scavenging method is an excellent means to determine the antioxidant activity of a variety of substances, such as scavengers of chain breaking antioxidants or lipid peroxyl radicals and hydrogen-donating antioxidants. The extracts in our study were found to have an appreciable scavenging activity of ABTS radical; this implies that they can be useful for the treatment of pathological damage caused by radicals. The ABTS scavenging ability of the methanol extract/fractions of $F$. olivieri suggests the electron/hydrogen abilities of the constituents present in this plant. Scavenging of ABTS has also been recorded in earlier reports [18, 49].

The reductive ability of antioxidant can be measured by reducing power. The $\mathrm{Fe}^{3+}$ transformation to $\mathrm{Fe}^{2+}$ in the presence of extracts by donating an electron is the assessment of reducing power. This reducing capacity of F. olivieri extract/fractions which involves breakdown of free radical chain by hydrogen atom donation is an indication of potential antioxidant activities [50].

In this experiment we have evaluated the protective potential of $F$. olivieri against acetaminophen induced hepatic toxicity in rat. Liver is a vital organ to detoxify xenobiotics, chemotherapeutic agents and environmental pollutants as it is the main organ involved in metabolism and excretion. Therefore, it is subjected to a wide range of disorders and diseases. Exposure to acetaminophen causes oxidative stress and liver injury probably through the drainage of mitochondrial glutathione [10]. ROS generated during this process may result in cell death and added to the hepatic damaging actions.

Percent increase in body weight and relative liver weight of rat was significantly decreased indicating the

Table 10 Effect of FOM on antioxidant enzyme activities in acetaminophen induced hepatotoxicity in rats

\begin{tabular}{lcccc}
\hline Treatment (mg/kg bw) & Catalase (U/mg protein) & SOD (U/mg protein) & GSH-Px (nM/min/mg protein) & GR (nM/min/mg protein) \\
\hline Control (Saline) & $5.85 \pm 0.13^{c}$ & $4.23 \pm 0.22^{\mathrm{d}}$ & $114.75 \pm 0.97^{c}$ & $127.53 \pm 1.90^{\mathrm{d}}$ \\
AMP 750 & $2.44 \pm 0.04^{\mathrm{a}}$ & $1.18 \pm 0.25^{\mathrm{a}}$ & $69.82 \pm 0.20^{\mathrm{a}}$ & $75.82 \pm 1.65^{\mathrm{a}}$ \\
AMP + Sily 50 & $5.68 \pm 0.21^{\mathrm{c}}$ & $4.32 \pm 0.12^{\mathrm{d}}$ & $116.14 \pm 0.31^{\mathrm{c}}$ & $125.31 \pm 2.29^{\mathrm{c}}$ \\
AMP + FOM 200 & $3.95 \pm 0.02^{\mathrm{b}}$ & $2.82 \pm 0.10^{\mathrm{b}}$ & $81.52 \pm 1.25^{\mathrm{b}}$ & $97.25 \pm 1.85^{\mathrm{b}}$ \\
AMP + FOM 400 & $5.71 \pm 0.15^{\mathrm{c}}$ & $3.78 \pm 0.57^{\mathrm{c}}$ & $110.59 \pm 2.18^{\mathrm{c}}$ & $116.84 \pm 1.39^{\mathrm{c}}$ \\
FOM 400 & $5.89 \pm 0.43^{\mathrm{c}}$ & $4.27 \pm 0.49^{\mathrm{d}}$ & $118.72 \pm 0.66^{\mathrm{c}}$ & $129.58 \pm 1.75^{\mathrm{d}}$ \\
\hline
\end{tabular}

Mean \pm SEM (06). Means with different superscript letters ${ }^{(-d)}$ ) within the column indicate significant difference $(p<0.05)$. AMP, acetaminophen; FOM, F. olivieri methanol extract 
Table 11 Effect of FOM on GSH, TBARS and DNA fragmentation in acetaminophen induced hepatotoxicity in rats

\begin{tabular}{lcccc}
\hline Treatment mg/kg bw & GSH $(\mu \mathrm{M} / \mathrm{g}$ tissue) & TBARS $(\mathrm{nM} / \mathrm{min} / \mathrm{mg}$ protein) & DNA fragmentation \% & Total protein $(\mu \mathrm{g} / \mathrm{mg}$ tissue) \\
\hline Control (Saline) & $25.52 \pm 0.63^{\mathrm{d}}$ & $1.85 \pm 0.01^{\mathrm{d}}$ & $6.12 \pm 0.01^{\mathrm{d}}$ & $4.90 \pm 0.17^{\mathrm{d}}$ \\
AMP 750 & $10.96 \pm 0.25^{\mathrm{a}}$ & $5.17 \pm 0.18^{\mathrm{a}}$ & $32.18 \pm 1.23^{\mathrm{a}}$ & $2.58 \pm 0.52^{\mathrm{a}}$ \\
AMP + Sily 50 & $25.01 \pm 0.64^{\mathrm{d}}$ & $1.71 \pm 0.04^{\mathrm{d}}$ & $7.11 \pm 0.16^{\mathrm{d}}$ & $3.96 \pm 0.63^{\mathrm{b}}$ \\
AMP + FOM 200 & $17.23 \pm 0.15^{\mathrm{b}}$ & $3.63 \pm 0.53^{\mathrm{b}}$ & $22.85 \pm 1.05^{\mathrm{b}}$ & $2.87 \pm 0.52^{\mathrm{a}}$ \\
AMP + FOM 400 & $22.76 \pm 0.14^{\mathrm{c}}$ & $2.51 \pm 0.16^{\mathrm{c}}$ & $15.42 \pm 1.32^{\mathrm{c}}$ & $3.64 \pm 0.13^{\mathrm{c}}$ \\
FOM 400 & $25.14 \pm 0.31^{\mathrm{d}}$ & $1.21 \pm 0.50^{\mathrm{e}}$ & $8.31 \pm 0.03^{\mathrm{d}}$ & $4.45 \pm 0.22^{\mathrm{d}}$ \\
\hline
\end{tabular}

Mean \pm SEM (06). Means with different superscript letters $\left.{ }^{\left({ }^{-e}-\right.}\right)$ within the column indicate significant difference $(p<0.05)$. AMP, acetaminophen; FOM, F. olivieri methanol extract

deleterious effects of acetaminophen. This decrease in relative liver weight might reflected the hydropic degeneration, haemorrhages and necrosis linked with fatty changes. The co-treatment of FOM resulted in a rise in the relative liver weight suggesting the protective potential of phytochemicals against the damaging action of acetaminophen. The observed decrease in the blood parameters such as $\mathrm{PCV} \%, \mathrm{Hb}, \mathrm{MCH}, \mathrm{MCHC}, \mathrm{WBC}$ and neutrophils while increase in the MCV\%, TLC, PLT, \%lymphocytes and \%granulocytes in the blood indicated the toxic effect of acetaminophen. The decrease in the haemoglobin and its related paramters reflected the enhanced hepatic red blood cell decomposition and decreased generation of red blood cells as manifested by the enhanced level of total bilirubin in this investigation. The enhanced level of lymphocytes and granulocytes in the blood circulation with acetaminophen indicated the rise of inflammatory response. Restoration of blood parameters towards the control level with FOM indicated the therapeutic efficacy of the phyto-chemicals present in the plant.

The determination of enzymes levels for instance ALT, AST, LDH is mostly used for the evaluation of hepatic injury. Intracellular enzymes can be measured in the serum after they released into circulation due to membrane damage or necrosis. Elevated levels of AST specifies hepatic injury as alanine is converted to glutamate and pyruvate which is catalysed by ALT and
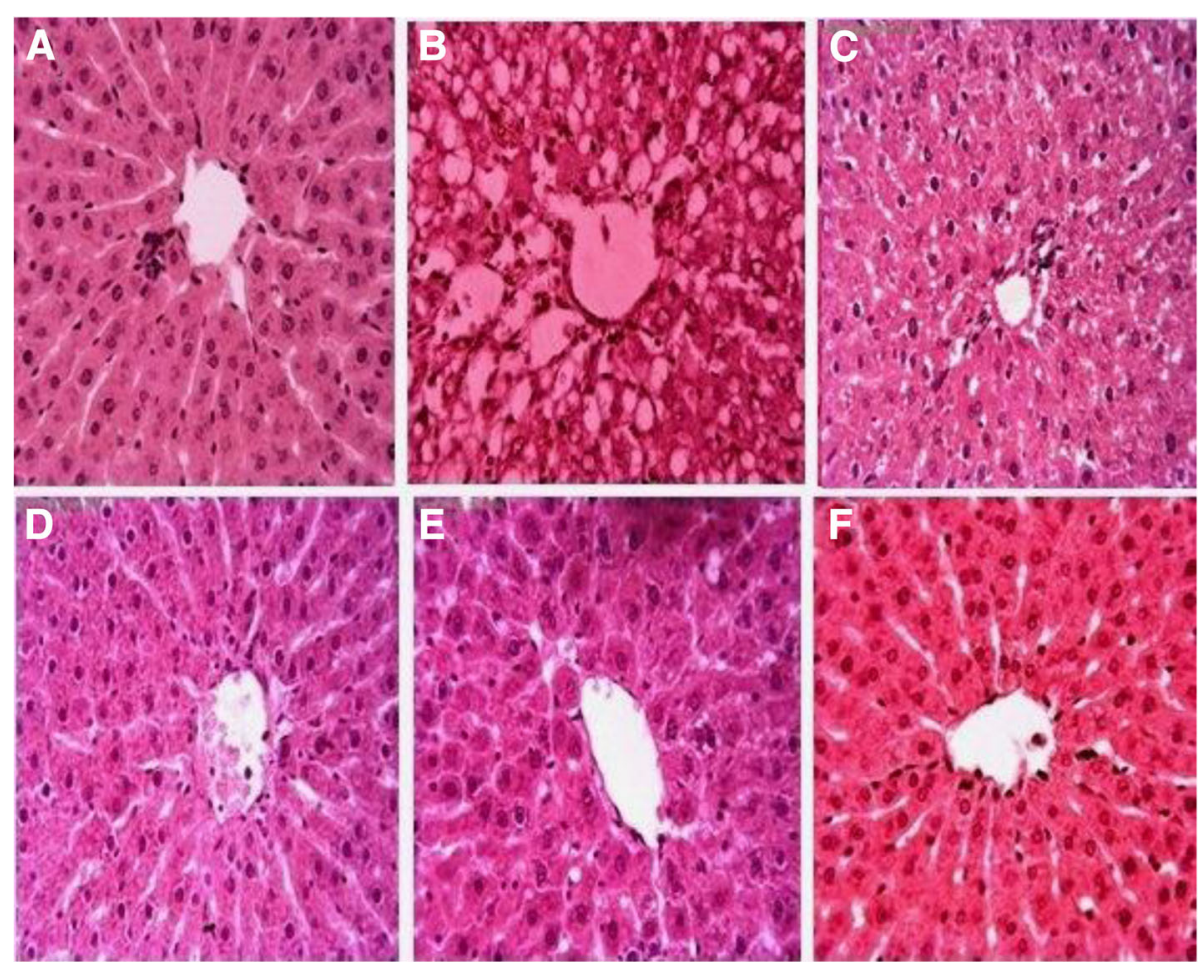

Fig. 3 Effect of F. olivieri on acetaminophen induced histopathology of liver. (a) Control group; (b) Acetaminophen 750 (mg/kg) treated group, (c) Acetaminophen + silymarin (50 mg/kg) treated group, (d) Acetaminophen + FOM (200 mg/kg) treated group (e) Acetaminophen + FOM (400 mg/kg) treated group, (f) FOM $(400 \mathrm{mg} / \mathrm{kg})$ treated group 
released in likely manner. Hence, ALT is a better parameter to identify hepatic damage as it is more specific to the liver. The higher concentrations of enzymes in the serum indicate loss of hepatic membrane functional integrity and cell leakage. Serum ALP, total protein and total bilirubin are also linked to the liver cell function. The elevation in serum ALP is because of increased synthesis, in presence of increasing biliary pressure [19, 20, 49]. Acetaminophen administration caused a significant rise of enzyme levels including AST, ALT, ALP, total bilirubin and decline in total protein in comparison to control. F. olivieri methanol extract administration significantly restored these parameters in a dose dependent manner. This reversal of the enzyme levels by the extract is probably because of their membrane stabilizing activity which prevents leakage of intracellular enzymes. This is in accordance with the generally established view that serum levels of transaminases restored to normal with the regeneration of liver cells and healing of liver parenchyma $[19,50]$.

The failure in the normal uptake, conjugation and excretion of the total bilirubin, triglycerides and albumin by the injured liver parenchyma might cause their elevation in serum. A very high level of hypercholesterolaemia may attain in acetaminophen induced toxicity, which frequently occur in biliary obstruction [49]. The triglycerides accumulation may also due to the disturbance or inhibition of triglycerides secreting mechanism [51]. The treatment with the extract almost entirely recovered these alterations and corrected the triglycerides metabolism.

The acetaminophen induced rise in hepatic TBARS levels propose increased lipid peroxidation which leads to tissue injury and collapse of antioxidant defence mechanism to avoid excessive free radicals formation. The lipid peroxidation is frequently observed with oxidative stress. NAPQI is likely to be unable to initiate a radical hydrogen abstraction from lipid molecules. Hence, reactive oxygen species including hydroxyl radicals, superoxide anions and hydrogen peroxide are required for initiation of lipid peroxidation. Nevertheless, decrease of NAPQI, which might take place due to the presence of flavoproteins, followed by reoxidation by oxygen could give rise to superoxide anions with a subsequent formation of reactive reduced oxygen species. Even protein bound NAPQI was suggested to be prone to one electron reduction. In the toxicity mechanism of acetaminophen, lipid peroxidation is considered to be a main initiation incident [10]. F. olivieri treatment to the rats significantly reduced the high levels of TBARS in dose dependent manner.

One of the sensitive indices in liver cell injury is decline of superoxide dismutase enzyme activity [54]. Superoxide dismutase is one of the vital enzymes in the enzymatic antioxidant defense system. It diminishes the toxic effect caused by superoxide anion by converting it into hydrogen peroxide. F. olivieri causes a significant elevation in liver superoxide dismutase activity and thus lessen free radical induced oxidative injury to liver. Catalase is an antioxidant enzyme which is commonly present in all animal tissues, and the highest activity is found in liver and red blood cells. Catalase defends the tissues from highly reactive hydroxyl radicals by decomposing hydrogen peroxide. Therefore decline in the catalase activity may cause various harmful effects due to hydrogen peroxide and superoxide radical assimilation. The standard hepatoprotective drug silymarin and the higher dose of extract in our study i.e. $400 \mathrm{mg} / \mathrm{kg}$ increase the catalase activity level. Restoration of catalase activity and thereby the decrease of hepatic damage might reflect the antioxidant activity of the phytoconstituents present in the plant used in this experiment.

Glutathione (GSH), a non-enzymatic antioxidant is one of the most plentiful tripeptide found in the liver. It gets rid of the reactive oxygen species for instance superoxide radicals, hydrogen peroxide, and preserves protein thiols of membrane. In acetaminophen intoxicated rats, the reduced levels of GSH are linked with increased lipid peroxidation. F. olivieri administration significantly restored the level of GST and GSH-Px in a dose dependent manner. The presence of polyphenolics was disclosed in preliminary phytochemical assessment of F. olivieri methanol extract. The observed hepatoprotective and antioxidant activities of $F$. olivieri are may be due to the presence of polyphenols such as rutin, catechin, gallic acid and other antioxidant phyto-chemicals $[55,56]$.

The histopathological analysis of liver confirmed the observed modification of serum enzymatic levels to liver injury and their attributes on health. The normal hepatic tissue in our study demonstrated the usual architecture with a central vein and hepatocytes radiating from it. The portal triad consisted of hepatic artery, portal vein and bile duct which constituted various zones surrounding these areas. Acetaminophen treatment produced centrizonal necrosis, hydropic and fatty changes with sinusoids congestion. Co-treatment with F. olivieri repaired the liver architecture and protected the hepatic tissue from degenerative and fatty alterations, by averting the toxic chemical reaction, oxidative stress, lipid peroxidation, molecular changes in the liver tissues, micro and macro vesicular fatty changes ultimately leading to necrosis. These findings are supported by the previous hepatoprotective abilities of plant extracts $[57,58]$.

\section{Conclusion}

Our study indicates that F. olivieri can serve as a natural source to develop the free radical scavengers which 
might be useful in the prevention of oxidative stress development. The significant correlation between the values of the concentration of phenolic and flavonoid compounds and antioxidant activity indicated that these compounds contribute to the antioxidant activity. Further studies should be done to isolate compounds from this plant that exhibit strong antioxidative activities. The results of in vivo study suggest that the $F$. olivieri has the ability to ameliorate acetaminopheninduced liver damage which might be associated with its antioxidant potential.

\begin{abstract}
Abbreviations
ACP: Acetaminophen; ALP: Alkaline phosphatase; ALT: Alanine transaminase; AST: Aspartate transaminase; CAT: Catalase; FOA: Fagonia olivieri soluble residual aqueous fraction of FOM; FOB: Fagonia olivieri n-butanol fraction of FOM; FOC: Fagonia olivieri chloroform fraction of FOM; FOE: Fagonia olivieri ethyl aceate fraction of FOM; FOH: Fagonia olivieri n-hexane fraction of FOM; FOM: Fagonia olivieri methanol extract; GR: Glutathione reductase; GSH: Rerduced glutathione; Hb: Hemoglobin; LDH: Lactate dehydrogenase; MCH: Mean corpuscular haemoglobin test; MCHC: Mean corpuscular haemoglobin concentration; MCV: Mean corpuscular volume; PCV: Packed cell volume; PLT: Platelet count; SOD: Superoxide dismutase;

TBARS: Thiobarbituric acid reactive substances; TLC: Total leukocyte count WBC: Whilte blood cells
\end{abstract}

\section{Acknowledgements}

MRK is intensely acknowledged for his kind supervision, expert guidance and substantial facilitations of all necessary materials and equipment. Dr. Bushra Mirza is also highly acknowledged for her assistance in HPLC.

\section{Funding}

The project was funded by the Department of Biochemistry Quaid-i-Azam University Islamabad Pakistan.

\section{Availability of data and materials}

All the data is contained in the manuscript.

\section{Authors' contributions}

UR made significant contribution to experimentation, acquisition and drafting of the manuscript. MRK has made substantial contribution to designing, analyzing and drafting of the manuscript. MS made a contribution in the experimentation and acquisition of the data. All authors read and approved the final manuscript.

\section{Authors' information}

MRK did his Diploma in Unani Medicine and Surgery (DUMS) and is a registered practitioner of the National Council for Tibb of Pakistan. $\mathrm{He}$ is working as Associate Professor at the Department of Biochemistry, Quaid-i-Azam University, Islamabad, Pakistan.

\section{Competing interest}

The authors declare that they have no competing interests.

\section{Consent for publication}

Not applicable.

\section{Ethics approval and consent to participate}

This study makes use of rats and the experimental protocol for the use of animal was approved (Bch\#0245) by the ethical board of Quaid-i-Azam University, Islamabad Pakistan.

\section{Author details}

'Department of Environmental Sciences, GC Women University Sialkot, Sialkot, Pakistan. ${ }^{2}$ Department of Biochemistry, Faculty of Biological Sciences, Quaid-i-Azam University, Islamabad 45320, Pakistan.
Received: 17 August 2016 Accepted: 27 October 2016

Published online: 09 November 2016

\section{References}

1. Scartezzini P, Speroni E. Review on some plants of Indian traditional medicine with antioxidant activity. J Ethnopharmacol. 2000;71(1):23-43.

2. Afsar T, Razak S, Khan MR, Mawash S, Almajwal A, Shabir M, Haq IU. Evaluation of antioxidant, anti-hemolytic and anticancer activity of various solvent extracts of Acacia hydaspica R. Parker aerial parts. BMC Complement Altern Med. 2016;16:258.

3. Mena S, Ortega A, Estrela J. Oxidative stress in environmental-induced carcinogenesis. Mutat Res Genet Toxicol Environ Mutagen. 2009;674:36-44.

4. Sajid M, Khan MR, Shah NA, Ullah S, Younis T, Majid M, Ahmad B, Nigussie D. Proficiencies of Artemisia scoparia aagainst $\mathrm{CCl}_{4}$ induced DNA damages and renal toxicity in rat. BMC Complement Altern Med. 2016;16:149.

5. Afsar T, Trembley JH, Salomon CE, Razak S, Khan MR, Ahmed K. Growth inhibition and apoptosis in cancer cells induced by polyphenolic compounds of Acacia hydaspica: involvement of multiple signal transduction pathways. Scientific Reports. 2016;6:23077.

6. Sasaki Y, Kawaquchi S, Kamaya A, Ohshita M, Kabasawa K, Iwama K, Taniguchi K, Tsuda S. The comet assay with 8 mouse organs: results with 39 currently used food additives. Mutat Res Genet Toxicol Environ Mutagen. 2002;519:103-19.

7. Gulcin I. Antioxidant activity of food constituents: an overview. Arch Toxicol. 2012;86:345-91.

8. Jalan R, Williams R, Bernuau J. Comment: paracetamol: are therapeutic doses entirely safe? Lancet. 2006;368:2195-6.

9. James LP, Mayeux PR, Hinson JA. Acetaminophern-induced hepatotoxicity. Drug Metab Dispos. 2003;31:1499-506.

10. McGill MR, Sharpe MR, Williams CD, Taha M, Curry SC, Jaeschke H. The mechanism underlying acetaminophen-induced hepatotoxicity in humans and mice involves mitochondrial damage and nuclear DNA fragmentation. J Clin Investig. 2012;122:1574-83.

11. Mabberley DI. The plant book. Cambridge: Cambridge University Press; 1987.

12. Barkatullah IM, Hussain F. Ethnobotanical studies of plants of Charkotli Hills, Batkhela District, Malakand, Pakistan. Front Biol China. 2009:4:539-48.

13. Saeed MA. Hamdard Pharmacopoeia of eastern medicine. Karachi: Hamdard Academy; 1969. p. 41-3.

14. Rashid U, Khan MR, Jan S, Bokhari J, Shah NA. Assessment of phytochemicals, antimicrobial and cytotoxic activities of extract and fractions from Fagonia olivieri (Zygophyllaceae). BMC Complement Altern Med. 2013;13:167.

15. Ahmad SS. Medicinal wild plants from Lahore-Islamabad motorway (M-2). Pak J Bot. 2007:39:355-75.

16. Prasad S, Kashyap RS, Deopujari JY, Purohit HJ, Taori GM, Daginawala HF. Effect of Fagonia Arabica (Dhamasa) on in vitro thrombolysis. BMC Complement Altern Med. 2007;7:36.

17. Ahmad S, Wariss HM, Alam MK, Anjum S, Ahmad K, Akhtar N. Hydro-alcoholic extracts of Fagonia indica Burm $f$ contribute anti-pyrexia activity to $E$ coli exposure in rabbits. International Journal of Science and Research. 2014;3:215-8

18. Pareek A, Godavarthi A, Issarani R, Nagori BP. Antioxidant and hepatoprotective activity of Fagonia schweinfurthii (Hadidi) Hadidi extract in carbon tetrachloride induced hepatotoxicity in HepG2 cell line and rats. J Ethnopharmacol. 2013;150:973-81.

19. Shehab NG, Abu-Gharbieh E, Bayoumi FA. Impact of phenolic composition on hepatoprotective and antioxidant effects of four desert medicinal plants. BMC Complement Altern Med. 2015;15:401.

20. Bagban IM, Roy SP, Chaudhary A, Bhandari KK. Hepatoprotective activity of the methanolic extract of Fagonia indica Burm in carbon tetra chloride induced hepatotoxicity in albino rats. Asian Pacific Journal of Tropical Biomedicine. 2012;2(3):S1457-60.

21. Hussain A, Zia M, Mirza B. Cytotoxic and antitumor potential of Fagonia cretica L. Turk J Biol. 2007:31:19-24.

22. Lam M, Carmichael AR, Griffiths HR. An aqueous extract of Fagonia cretica induces DNA damage, cell cycle arrest and apoptosis in breast cancer cells via FOXO3a and p53 expression. PLoS One. 2012;7(6):e40152.

23. Kim DO, Jeong SW, Lee CY. Antioxidant capacity of phenolic phytochemicals from various cultivars of plums. Food Chem. 2003;81:321-6. 
24. Park YS, Jung ST, Kang SG, Heo BK, Arancibia-Avila P, Toledo F, Drzewiecki J, Namiesnik J, Gorinstein S. Antioxidants and proteins in ethylene-treated kiwifruits. Food Chem. 2008;107:640-8.

25. Mensor LL, Menezes FS, Leitao GG, Reis AS, Dos Santos TC, Coube CS, Leitao SG. Screening of Brazilian plant extracts for antioxidant activity by the use of DPPH free radical method. Phytother Research. 2001;15:127-30.

26. Ponti V, Dianzani MU, Cheeseman K, Slater TF. Studies on the reduction of nitroblue tetrazolium chloride mediated through the action of NADH and phenazine methosulphate. Chemico-Biological Interaction. 1978;23:281-91.

27. Prieto $P$, Manuel $P$, Miguel A. Spectrophotometric quantitation of antioxidant capacity through the formation of a phosphomolybdenum complex: specific application to the determination of vitamin E. Anal Biochem. 1999;269:337-41.

28. Miller NJ, Castelluccio C, Tijburg L, Rice-Evans C. The antioxidant properties of the aflavins and their gallate esters-radical scavengers or metal chelators? FEBS Letter. 1996;392:40-4.

29. Halliwell B, Gutteridge JMC, Aruoma Ol. The deoxyribose method: a simple "test-tube" assay for determination of rate constants for reactions of hydroxyl radicals. Annals of Biochemistry. 1987;165:215-9.

30. Ruch RJ, Cheng S-J, Klaunig JE. Prevention of cytotoxicity and inhibition of intercellular communication by antioxidant catechins isolated from Chinese green tea. Carcinogenesis. 1989;10(6):1003-8.

31. Landry ML, Stanat S, Biron K, Brambilla D, Britt W, Jokela J, Chou S, Drew WL, Erice A, Gilliam B, Lurain N, Manischewitz J, Miner R, Nokta M, Reichelderfer P, Spector S, Weinberg A, Yen-Lieberman B, Crumpacker C. A standardized plaque reduction assay for determination of drug susceptibilities of cytomegalovirus clinical isolates. Antimicrob Agents Chemother. 2000;44(3): 688-92.

32. Organization for Economic Co-operation and Development: OECD guideline for testing chemicals 425 . Acute oral toxicity-up and down procedure. 2001;2:1216

33. Rajkapoor B, Venugopal Y, Anbu J, Harikrishnan N, Gobinath M, Ravichandran V. Protective effect of Phyllanthus polyphyllus on acetaminophen induced hepatotoxicity in rats. Pak J Pharm Sci. 2008;21:57-62.

34. Chance B, Maehly A. [136] Assay of catalases and peroxidases. Methods Enzymol. 1955;2:764-75.

35. Kakkar P, Das B, Viswanathan P. A modified spectrophotometric assay of superoxide dismutase. Indian J Biochem Biophys. 1984;21(2):130-2.

36. Carlberg I, Mannervik B. Purification and characterization of the flavoenzyme glutathione reductase from rat liver. J Biol Chem. 1975;250(14):5475-80.

37. Mohandas J, Marshall JJ, Duggin GG, Horvath JS, Tiller DJ. Differential distribution of glutathione and glutathione-related enzymes in rabbit kidney: possible implications in analgesic nephropathy. Biochem Pharmacol. 1984;33(11):1801-7.

38. Jollow D, Mitchell J, Zampaglione NA, Gillette J. Bromobenzene-induced liver necrosis. Protective role of glutathione and evidence for 3, 4bromobenzene oxide as the hepatotoxic metabolite. Pharmacology. 1974;11(3):151-69.

39. Iqbal M, Sharma S, Rezazadeh H, Hasan N, Abdulla M, Athar M. Glutathione metabolizing enzymes and oxidative stress in ferric nitrilotriacetate mediated hepatic injury. Redox Rep. 1996;2(6):385-91.

40. Wu B, Ootani A, Iwakiri R, Sakata Y, Fujise T, Amemori S, Yokoyama F, Tsunada S, Fujimoto K. T cell deficiency leads to liver carcinogenesis in Azoxymethane-treated rats. Society for Experimental Biology and Medicine. 2005;231:91-8

41. Oshaghi EA, Khodadadi I, Tavilani H, Goodarzi MT. Dill tablet: a potential antioxidant and anti-diabetic medicine. Asian Pacific Journal of Tropical Biomedicine. 2015;5:720-7.

42. Ines U, Federico L. Plant polyphenol antioxidants and oxidative stress. Biol Res. 2000;33:55-64.

43. Sini H, Devi KS. Antioxidant activities of chloroform extract of Solanum trilobatum. Pharm Biol. 2004;42:462-6.

44. Oshaghi EA, Khodadadi I, Tavilani H, Goodarzi MT. Aqueous Extract of Anethum graveolens L. has potential antioxidant and antiglycation effects. Iranian Journal of Medical Sciences. 2016;41:328-33.

45. Shahidi F. Natural antioxidants. An overview. In: Natural antioxidants, chemistry, health effects and applications. Champaign: AOCS Press; 1997. p. 1-11.

46. Mandel S, Youdim MB. Catechin polyphenols: neurodegeneration and neuroprotection in neurodegenerative diseases. Free Radic Biol Med. 2004;37(3):304-17.
47. Kamalakkannan N, Prince PS. Rutin improves the antioxidant status in streptozotocin-induced diabetic rat tissues. Mol Cell Biochem. 2006;293:211-9

48. Yang J, Guo J, Yuan J. In vitro antioxidant properties of rutin. LWT-Food Science and Technology. 2008;41(6):1060-6.

49. Zhao B, Hu M. Gallic acid reduces cell viability, proliferation, invasion and angiogenesis in human cervical cancer cells. Oncol Lett. 2013;6(6):1749-55.

50. Sajid M, Khan MR, Shah NA, Shah SA, Ismail H, Younis T, Zahra Z. Phytochemical, antioxidant and hepatoprotective effects of Alnus nitida bark in carbon tetrachloride challenged Sprague Dawley rats. BMC Complement Altern Med. 2016;16:268.

51. Kosanic M, Rankovic B. Lichens as possible sources of antioxidants. Pakistan Journal of Pharmaceutical Science. 2011;24(2):165-70.

52. Khan RA, Khan MR, Sahreen S. Attenuation of $\mathrm{CCl}_{4}$-induced hepatic oxidative stress in rat by Launaea procumbens. Exp Toxicol Pathol. 2013:65:319-26.

53. Zheng GO, Kenny PM, Lam LK. Anethofuran, carvone and limonene: potential chemopreventive agents from dill weed oil and caraway oil. Planta Med. 1992;58:338-41.

54. Dorman HJ, Kosar M, Kahlos K, Holm Y, Hiltunen R. Antioxidant properties and composition of aqueous extracts from Mentha species, hybrids, varieties, and cultivars. Journal of Agricultural Food Chemistry. 2003:51:4563-9.

55. Hazarika N, Singh P, Hussain A, Das S. Phenolics content and antioxidant activity of crude extract of Oldenlandia corymbosa and Bryophyllum pinnatum. Research Journal of Pharmaceutical Biology and Chemical Science. 2012:3(2):297-303.

56. Mohammadi A, Mirzaei F, Jamshidi M, Yari R, Pak S, Sorkhani AN, Norouzian P, Abdolkarimi V, Oshaghi EB. The in vivo biochemical and oxidative changes by ethanol and Opium consumption in Syrian hamsters. International Journal of Biology. 2013;5:14-22.

57. Alkreathy HM, Khan RA, Khan MR, Sahreen $\mathrm{S}$. $\mathrm{CCl}_{4}$ induced genotoxicity and DNA oxidative damages in rats; hepatoprotective effect of Sonchus arvensis. BMC Complement Altern Med. 2014;14:452

58. Oshaghi EA, Khodadadi I, Tavilani H, Goodarzi MT. Effect of dill tablet (Anethum graveolens $\mathrm{L}$ ) on antioxidant status and biochemical factors on carbon tetrachloride-induced liver damage on rat. International Journal of Applied and Basic Medical Research. 2016;6:111-4.

\section{Submit your next manuscript to BioMed Central and we will help you at every step:}

- We accept pre-submission inquiries

- Our selector tool helps you to find the most relevant journal

- We provide round the clock customer support

- Convenient online submission

- Thorough peer review

- Inclusion in PubMed and all major indexing services

- Maximum visibility for your research

Submit your manuscript at www.biomedcentral.com/submit
Biomed Central 